DEPARTAMENTO DE INDÚSTRIA, INSPEÇÃo E CONSERVAÇÃo DE.

PRODUTOS ALIMENTICIOS DE ORIGEM ANIMAL

Diretor: Prof. Dr. Paschoal Mucciolo

\title{
CAUSAS DE REJEIÇÃO DE SUINOS ABATIDOS NO BRASIL CENTRAL (*) NOS ANOS DE 1936 A 1949
}

\author{
(CAUSES OF SWINE REJECTIONS IN SLAUGHTERHOUSES OF \\ CENTRAI, BRAZIL, FROM 1936 TO 1949)
}

\author{
Pallo de Assis Ribeiro \\ Assistente
}

\section{INTRODUÇत̃O}

A importância dos estudos referentes à incidência das várias causas de rejeição de produtos alimentícios de origem animal é ponto pacífico em nossos dias, dado o extremo valor por êles assumido na alimentação humana. Em se tratando, porém, da carne, o assunto assume importância ainda maior não só do ponto de vista alimentar, mas também no que se refere à defesa dos rebanhos, impossivel de ser bem planificada e executada sem dados exatos que revelem a incidência percentual das várias zoonoses; atente-se também à relevância dêstes estudos no referente à saúde humana, de vez que é sabidamente grande o número de doenças que podem ser transmitidas ao homem por carnes contaminadas ou parasitadas. E' de lamentar-se o fato de ainda não contarmos com um serviço eficiente de estatística sanitária animal, muito embora, já em 1926, Pecego lembrasse a oportunidade de sua criação.

Desta forma, outro não é o objetivo do presente trabalho, senão fornecer aos que se dedicam a estudos não só relativos à patologia animal e comparada, mas também aos que se interessam pela criação e aproveitamento do rebanho suíno nacional, dados concretos, obtidos em fontes oficiais, referentes às principais causas de rejeição de vísceras e de carcaças de suínos, verificadas em estabelecimentos abatedores situados no Brasil Central, e funcionando sob inspeção federal.

(*) $\Lambda$ região denominada Brasil Central compreendia, até 1948, para os fins de Inspeção Federal, os Estados de São Paulo, Mato Grosso, Goiás e a parte do Estado de Minas Gerais designada como "Triângulo, Mineiro". Dêsse ano em diante, entretanto, a Inspetoria de Produtos de Origem Animal do Ministério da Agricultura, sediada em São Paulo, só inspeciona os estabelecimentos abatedores situados nos Estadios de São Paulo e Mato Grosso. 
Para a realização dêste trabalho contamos com a extrema boa vontade do Inspetor-Chefe em São Paulo, da Inspetoria Regional de Produtos de Origem Animal do Ministério da Agricultura, o qual, demonstrando alto espírito de compreensão, nos franqueou a Secção de Estatística da repartição que dirige.

Mencionaremos inicialmente a incidência das causas de rejeição de carcaças, enumerando as várias entidades nosológicas determinantes não só de condenação, mas também de envio de carcaças à banha, à conserva e à salga. As percentagens de incidência incluem também as causas de rejeição que se apresentaram num tal estado evolutivo ou de tal forma localizadas, que as carcaças não foram apreendidas. Incluimos também nos quadros, os animais que sucumbiram antes de entrarem na sala de matança, vítimas não só de doenças que os atacaram em viagem, mas também das péssimas condições em que foram transportados.

$\mathrm{Na}$ segunda parte do trabalho são apresentadas as várias causas de rejeição de cabeças e de vísceras, assim como sua média percentual de incidência.

$\mathrm{Na}$ terceira parte são comentadas as percentagens de incidência no Brasil das principais zoonoses, comparando-se-as com as de outros países.

Acreditamos que os elementos apresentados, dada a extensão do período estudado e o número de animais examinados, refletem, razoàvelmente, o panorama nosológico não só da regiấo em estudo, mas também das outras que a esta forneceram suinos para abate, excluindo-se naturalmente algumas zoonoses, principalmente as de caráter agudo e as que ocorreram em surtos epizoóticos, cujo maior dano foi causado antes dos animais atingirem as salas de matança ou mesmo antes de serem embarcados nas zonas de criação.

As percentagens referem-se ao total de suinos abatidos sob as vistas da Inspeção Veterinária Federal que foi, no período estudado, de 4.463 .848 , representando parte (aproximadamente $50 \%$ ) do total de suínos abatidos na região nesse período, de vez que o restante foi sacrificado em estabelecimentos não inspecionados, sendo liberados ao consumo sem prévio exame higiênico. Não é necessário ressaltar a gravidade desta última afirmação; atente-se sòmente ao fato de que alguns milhōes de suínos foram abatidos e dados ao consumo a grandes centros, sem inspeção sanitária alguma, com real perigo para a saúde pública. A solução dêste problema baseia-se na obrigatoriedade do exame de todos os animais destinados ao abate. Não se compreende como, em nossos dias, conhecendo-se série grande de moléstias infectuosas e parasitárias indiscutivelmente transmissíveis ao homem pela carne, ainda se permitam sejam entregues ao consumo público animais abatidos em estabelecimentos onde não é exercida inspecção sanitária alguma.

0 quadro A, que apresentamos em seguida, enumera o total anual de suínos abatidos no Brasil Central sob Inspeção Veterinária Federal, de 1936 a 1949. 
QUADRO A - MATANÇAS

\begin{tabular}{c|c}
\hline A n o s & Suínos abatidos \\
\hline 1936 & 287.582 \\
1937 & 268.771 \\
1938 & 284.364 \\
1939 & 322.830 \\
1940 & 318.214 \\
1941 & 319.312 \\
1942 & 260.679 \\
1943 & 308.122 \\
1944 & 381.324 \\
1945 & 433.853 \\
1946 & 369.000 \\
1947 & 264.000 \\
1948 & 314.990 \\
1949 & $330.80 \tau$ \\
\hline I' o t a 1 & 4.463 .848 \\
\hline
\end{tabular}

MA'IERIAI, E METODO

O trabalho baseou-se em fichas de inspeção existentes na Secção de Estatística da Inspetoria Regional de Produtos de Origem Animal do Ministério da Agricultura, sediada em São Paulo.

Todos os estabelecimentos abatedores, sob inspeção federal, situados no Brasil Central, anotam as diversas causas de rejeição em fichas que são remetidas periòdicamente à Chefia. Esta reune os elementos em novas fichas, onde são relatadas, numèricamente, as diversas causas de rejeição, assim como o destino dado às carcaças.

Note-se, entretanto, que nem todos os suínos abatidos nos estabelecimentos situados na região estudada, provieram da mestna. pôsto que grande número dêles foi adquirido nos Estados vizinhos, principalmente no Paraná, em Minas Gerais e em Goiás.

Nosso trabalho constou, após revisão geral, em enumerar as diferentes causas de rejejção, calalogadas ano por ano, de 1936 a 1949, assinalando o destino dado às carcaças: condenação, aproveitamento condicional à fabricação de banha, de conservas, de produtos salgados e não apreensão.

Os quadros referem-se a tôdas as causas de rejeição de carcaças, de cabeças e de vísceras; nêles são referidos o número total e a média percentual das incidências nos 14. anos estudados. 
QUADRO I - TOTAIS E PERCENTAGENS DE INCIDENCIA DAS VARIAS CAUSAS DE APREENS̃̃O DE CARCAÇAS DE SUINOS

(Percentagens calculadas sôbre o total de matanças $-4.463 .848)$ - 1936 a 1949

\begin{tabular}{|c|c|c|c|c|c|c|c|}
\hline & 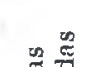 & $\begin{array}{c}\text { Carcaç } \\
\text { cone }\end{array}$ & $\begin{array}{l}\text { as apro } \\
\text { licionaln }\end{array}$ & $\begin{array}{l}\text { tadas } \\
\text { ite }\end{array}$ & 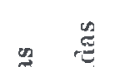 & & $=x$ \\
\hline 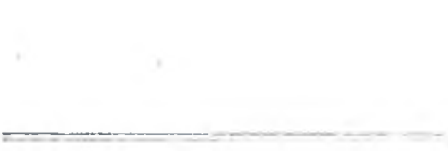 & 㤩 & Banha & 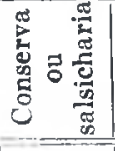 & Salga & 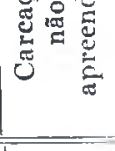 & 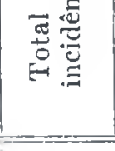 & 氞 \\
\hline Tuberculose $\quad \ldots \ldots \ldots \ldots \ldots$ & 15.216 & 18.396 & 9.599 & 3.097 & 55.712 & 102.020 & 2,285 \\
\hline Brucelose $\quad \ldots \ldots \ldots \ldots \ldots \ldots$ & 12 & 158 & 3.489 & 440 & $\ldots$ & 4.099 & 0,092 \\
\hline Aftosa $\quad \ldots \ldots \ldots \ldots \ldots \ldots \ldots$ & 1 & - & 1 & 4 & 37 & 43 & $\longleftarrow$ \\
\hline Peste suina $\ldots \ldots \ldots \ldots \ldots \ldots$ & 262 & 886 & 165 & 107 & - & 1.420 & 0,032 \\
\hline$\ldots \ldots \ldots \ldots \ldots \ldots$ & 5 & - & II & - & - & 16 & - \\
\hline Cisticercose $\quad \ldots \ldots \ldots \ldots \ldots \ldots$ & 2.708 & 184.665 & 29.718 & 42.883 & 24.044 & 284.018 & 6,362 \\
\hline Sarcosporidiose $\quad \ldots \ldots \ldots \ldots$ & - & 37 & 174 & 13 & 7 & 231 & 0,005 \\
\hline Sarna $\ldots \ldots \ldots \ldots \ldots \ldots \ldots$ & - & 15 & 28 & 103 & 5.176 & 5.322 & 0,119 \\
\hline Sapremia $\quad \ldots \ldots \ldots \ldots \ldots$ & 1 & $\longrightarrow$ & - & - & 一 & 1 & - \\
\hline Seticemia $\quad \ldots \ldots \ldots \ldots \ldots$ & $\tilde{\tau}$ & - & $\ldots$ & - & - & 7 & 一 \\
\hline Piemia $\quad \ldots \ldots \ldots \ldots \ldots \ldots$ & 543 & - & - & 一 & 一 & 543 & 0,012 \\
\hline Piobacilose $\quad \ldots \ldots \ldots \ldots \ldots \ldots$ & 27 & - & 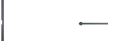 & - & - & 27 & - \\
\hline Carcinoma $\quad \ldots \ldots \ldots \ldots \ldots$ & - & - & 1 & 一 & - & $\mathbf{1}$ & - \\
\hline Colorações anormais $\quad \ldots \ldots$ & 2.285 & 64 & 9 & 35 & 26 & 2.419 & 0,054 \\
\hline Melanose $\quad \ldots \ldots \ldots \ldots \ldots \ldots$ & - & 一 & 21 & 1 & $\ldots$ & 22 & - \\
\hline Abcessos $\quad \ldots \ldots \ldots \ldots \ldots \ldots$ & 156 & 3.688 & 965 & 382 & 8.193 & 13.384 & 0,300 \\
\hline Bronquite e broncopneumonia & 21 & 75 & 457 & 38 & - & 591 & 0,013 \\
\hline Asfixia $\quad \ldots \ldots \ldots \ldots \ldots \ldots$ & 1 & 209 & 3 & - & $\cdots$ & 213 & 0,004 \\
\hline Gangrena $\quad \ldots \ldots \ldots \ldots \ldots$ & 8 & 1 & - & - & - & 9 & $\cdots$ \\
\hline Pleurite - aderências ...... & 34 & 250 & 6 & 19 & 200 & 509 & 0,011 \\
\hline Necrose $\quad \ldots \ldots \ldots \ldots \ldots \ldots \ldots$ & 2 & -- & -- & - & - & 2 & - \\
\hline$\ldots \ldots \ldots \ldots \ldots \ldots$ & - & 14 & 1.061 & 316 & 10.180 & 11.571 & 0,254 \\
\hline Artrite $\quad \ldots \ldots \ldots \ldots \ldots \ldots$ & 2 & - & - & -- & - & 2 & - \\
\hline Pericardite $\quad \ldots \ldots \ldots \ldots \ldots \ldots$ & 一 & 1 & - & - & - & 1 & $-\cdots$ \\
\hline Miocardite $\quad \ldots \ldots \ldots \ldots \ldots \ldots$ & 2 & - & $\ldots$ & - & - & 2 & $\longrightarrow$ \\
\hline$\ldots \ldots \ldots \ldots \ldots$ & 37 & 2.016 & $\ldots$ & -1 & $\ldots$ & 2.083 & 0,047 \\
\hline Hepatite $\quad \ldots \ldots \ldots \ldots \ldots \ldots$ & $\cdots$ & - & $\cdots$ & 1 & - & 1 & - \\
\hline Mamite $\quad \ldots \ldots \ldots \ldots \ldots \ldots$ & 一 & $一$ & 1 & 5 & 5 & 11 & - \\
\hline Dermatite $\quad \ldots \ldots \ldots \ldots \ldots \ldots$ & 20 & 5 & 741 & 1 & 8 & 775 & 0,017 \\
\hline$\ldots \ldots \ldots \ldots \ldots \ldots$ & 1 & I & - & - & - & 2 & \\
\hline$\ldots \ldots \ldots \ldots \ldots \ldots$ & 1 & - & -- & 一 & - & 1 & - \\
\hline Hipoternia $\quad \ldots \ldots \ldots \ldots \ldots$ & 2 & - & - & -- & - & 2 & - \\
\hline Caquexia -- Magreza ..... & 325 & 一 & 140 & 81 & $\cdots$ & 516 & 0,012 \\
\hline Gestą̧ão avançada ......... & 4 & 一 & - & 一 & 一 & 4 & $\cdots$ \\
\hline Fratura $\ldots \ldots \ldots \ldots \ldots \ldots$ & - & - & 1 & $\ldots$ & $\cdots$ & 1 & - \\
\hline Matanças de emergência ...... & - & - & 148 & 2 & - & 150 & 0,$00 ; 3$ \\
\hline$\ldots \ldots \ldots \ldots$ & - & $\ldots$ & $\longrightarrow$ & - & 10 & 10 & - \\
\hline Congestão $\quad \ldots \ldots \ldots \ldots \ldots$ & - & 39 & - & 3 & 9 & 51 & -- \\
\hline Intoxicacão alimentar $\ldots \ldots \ldots$ & 1 & - & 一 & - & - & $\mathbf{1}$ & $\ldots$ \\
\hline Contusões $\quad \ldots \ldots \ldots \ldots \ldots$ & 415 & 5.117 & 1.976 & 4.661 & 971 & 13.140 & 0,294 \\
\hline Mortos nos currais ......... & 22.114 & - & - & - & - & 22.114 & 0,495 \\
\hline To t a i s & 44.213 & 215.667 & 18.715 & 52.192 & $10+.578$ & 一 & 10,425 \\
\hline
\end{tabular}




\section{RESULTADOS}

Para clareza e facilidade de compreensão, organizamos os quadros que são apresentados a seguir.

\section{QUADIRO II -- DESTINO DADO AS CARCAÇAS RFIEITADAS}

SUINOS - 1936 a 1949

\begin{tabular}{|c|c|c|c|}
\hline & $\begin{array}{c}\text { No de carcaças } \\
\text { rejeitadas }\end{array}$ & $\begin{array}{l}\text { Pêso em kg (mé- } \\
\text { dia de } 70 \mathrm{~kg} \text { por } \\
\text { unidade) }\end{array}$ & $\begin{array}{c}\% \text { s/ o total } \\
\text { abatido }\end{array}$ \\
\hline Carcacas condenadas $\ldots . \ldots \ldots$ & 44213 & 3.094 .910 & 0,990 \\
\hline $\begin{array}{l}\text { Carcaças aproveitadas condicio- } \\
\text { nalmente a fabricação de ba- } \\
\text { nha } \quad \ldots \ldots \ldots \ldots \ldots \ldots \ldots \ldots \ldots\end{array}$ & 215.667 & 15.096 .690 & 4,831 \\
\hline $\begin{array}{l}\text { Carcaças aprovejtadas condicio- } \\
\text { nalmente à fabricação de con- } \\
\text { servas } \quad \ldots \ldots \ldots \ldots \ldots \ldots \ldots \ldots \ldots\end{array}$ & 48.715 & 3.410 .050 & 1,091 \\
\hline $\begin{array}{l}\text { Carcaças aproveitadas condicio } \\
\text { nalmente ì salga } \ldots \ldots \ldots \ldots \ldots\end{array}$ & $52.19+2$ & 3.653 .440 & 1,169 \\
\hline $\begin{array}{l}\text { Total de carcacas retiradas do } \\
\text { consumo como carne fresca .. }\end{array}$ & 360.787 & 25.255 .090 & 8,081 \\
\hline
\end{tabular}

(2UADRO MI - PRINCIPAIS CAUSAS DH REJHIÇO DE CARCACAS DE SUINOS -.. 1936 a $1949 \ldots$

\begin{tabular}{|c|c|c|c|}
\hline & $\begin{array}{l}\text { No de carcaças re- } \\
\text { tiradas do consumo } \\
\text { como calne fresca }\end{array}$ & $\begin{array}{l}\text { \% sôbre o total de } \\
\text { carcaças retiradas } \\
\text { do consumo como } \\
\text { carne fresca }\end{array}$ & $\begin{array}{l}\% \text { s/ o total } \\
\text { abatido }\end{array}$ \\
\hline$\ldots \ldots \ldots \ldots$ & 259.974 & 72,055 & 5,824 \\
\hline Tuberculose & 46.308 & 12,835 & 1,037 \\
\hline $\begin{array}{c}\text { Chegados mortos e mortos nos } \\
\text { currais } \ldots \ldots \ldots \ldots \ldots \ldots \ldots \ldots\end{array}$ & 22.114 & 6,129 & 0,495 \\
\hline Contusôes & 12.169 & 3,373 & 0,273 \\
\hline
\end{tabular}

QUADRO IV - CAUSAS PRINCIPAIS DE CONDKNAÇÃO DE CARCAÇAS DE SUINOS ('Total - - 4.213) - 1936 ; 1949

\begin{tabular}{|c|c|c|c|}
\hline & $\begin{array}{l}\text { Ne de } \\
\text { carcaças }\end{array}$ & $\begin{array}{l}\text { \% sôbre o total } \\
\text { de carcaças } \\
\text { condenadas }\end{array}$ & $\begin{array}{l}\text { Pêso em kg } \\
70 \mathrm{~kg} \text { por unidade }\end{array}$ \\
\hline $\begin{array}{c}\text { Chegados mortos e mortos nos } \\
\text { currais } \quad \ldots \ldots \ldots \ldots \ldots \ldots \ldots\end{array}$ & 22.114 & 50,016 & 1.547 .980 \\
\hline 'Tuberculose & 15.216 & 33,962 & 1.065 .120 \\
\hline Cisticercose $\quad \ldots \ldots$. & 2.708 & 6,125 & 189.560 \\
\hline Colorações anomuas $\ldots \ldots \ldots$. & 2.28 .5 & 5,168 & 169.950 \\
\hline
\end{tabular}


QUADRO $v$ - CARCAÇAS APROVEITADAS PARA FABRICAÇAO DE, BANHA CAUSAS PRINCIPAIS (Total - 215.667) SUfNOS - 1936 a 1949

\begin{tabular}{|c|c|c|c|c|}
\hline & & $\begin{array}{c}\mathrm{N}^{\circ} \mathrm{de} \\
\text { carcaças }\end{array}$ & $\begin{array}{c}\text { \% sôbre o total de } \\
\text { carcaças destinadas } \\
\text { a banha }\end{array}$ & $\begin{array}{ll}\text { Pêso em } \mathrm{kg} \\
70 \mathrm{~kg} \text { por unidade }\end{array}$ \\
\hline Cisticercose & $\ldots \ldots \ldots \ldots \ldots$ & 184.665 & 85,625 & 12.926 .550 \\
\hline Tuberculose & $\ldots \ldots \ldots \ldots \ldots$ & 18.396 & 8,530 & 1.287 .720 \\
\hline Contusões & & 5.117 & 2,373 & 358.190 \\
\hline Abcessos & $\ldots \ldots \ldots \ldots \ldots$ & 3.688 & 1,710 & 258.160 \\
\hline Peritonite & & 2.046 & 0,949 & 143.220 \\
\hline
\end{tabular}

\section{QUADRO VI - CARCAÇAS APROVEITADAS PARA A FABRICAÇĀO DE} ' CONSERVAS - CAUSAS PRINCIPAIS (Total - 46.715)

SUINOS - 1936 a 1949

\begin{tabular}{|c|c|c|c|c|}
\hline & 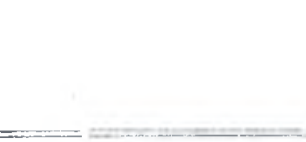 & $\begin{array}{l}\text { Ne de } \\
\text { carcaças }\end{array}$ & $\begin{array}{l}\% \text { s/ o total de car- } \\
\text { caças destinadas a } \\
\text { fabricação de con- } \\
\text { servas }\end{array}$ & $\begin{array}{l}\text { Pêso em kg } \\
\text { 70 kg por unidade }\end{array}$ \\
\hline Cisticercose & $\ldots \ldots \ldots \ldots$ & 29.718 & 61,003 & 2.080 .260 \\
\hline Tuberculose & . & 9.599 & 19,704 & 671.930 \\
\hline Brucelose & . & 3.489 & 7,162 & 244.230 \\
\hline Contusões & & 1.976 & 4,056 & 138.320 \\
\hline Abcessos & & 965 & 1,981 & 67.550 \\
\hline Dermatite & $\ldots \ldots \ldots \ldots \ldots \ldots$ & 741 & 1,521 & 51.870 \\
\hline
\end{tabular}

QUADRO VIR - CARCAÇAS DESIINADAS A SALGA - CAUSAS PRINCIPAIS (Total - 52.192)

SUINOS - 1936 a 1949

\begin{tabular}{lc|c|c|c}
\hline & $\begin{array}{c}\text { No de } \\
\text { carcaças }\end{array}$ & $\begin{array}{c}\text { \% s/ o total de car- } \\
\text { caças destinadas a } \\
\text { salga }\end{array}$ & $\begin{array}{c}\text { Pêso em kg (70 k } \\
\text { por unidade) }\end{array}$ \\
\hline Cisticercose & $\ldots \ldots \ldots \ldots \ldots \ldots \ldots$ & 42.883 & $82,16 \%$ & 3.001 .810 \\
Contusões & $\ldots \ldots \ldots \ldots \ldots \ldots \ldots \ldots$ & 4.661 & 8,930 & 326.270 \\
Tuberculose & $\ldots \ldots \ldots \ldots \ldots \ldots \ldots$ & 3.097 & 5,934 & 216.790 \\
\hline
\end{tabular}


QUADRO VIII - TOTAIS E PERCENTAgens DE INCIDencIa DAS CA

(P'ercentagens calculadas sôbre o total de ci

\begin{tabular}{|c|c|c|c|c|c|c|c|}
\hline & Cabeças & $\%$ & Línguas & $\%$ & Pulmões & $\%$ & Coraç⿸̃ \\
\hline 'Tuberculose & 99.386 & 2,226 & 45.493 & 1,019 & 41.836 & 0,937 & 34) \\
\hline Actinomicose $\quad \ldots \ldots \ldots \ldots \ldots \ldots \ldots \ldots \ldots$ & 1 & - & - & - & - & - & - \\
\hline Brucelose $\quad \ldots \ldots \ldots \ldots \ldots \ldots \ldots \ldots \ldots$ & I & - & - & - & - & - & - \\
\hline Aftosn $\quad \ldots \ldots \ldots \ldots \ldots \ldots \ldots \ldots \ldots \ldots \ldots \ldots \ldots$ & - & - & 109 & - & - & - & - \\
\hline Peste suina $\ldots \ldots \ldots \ldots \ldots \ldots \ldots \ldots \ldots \ldots \ldots \ldots \ldots \ldots \ldots \ldots$ & 768 & 0,017 & 824 & 0,018 & 811 & 0,018 & 196 \\
\hline C. cellulosae & 251.192 & 5,627 & 239.679 & 5,369 & 9 & - & 235.949 \\
\hline Fasciola hepritica $\ldots \ldots \ldots \ldots \ldots \ldots \ldots$ & - & - & - & - & - & - & - \\
\hline C. tenuicolis $\ldots \ldots \ldots \ldots \ldots \ldots \ldots \ldots \ldots \ldots \ldots$ & - & - & - & - & - & - & - \\
\hline ìquinococose ou hidatidose $\ldots \ldots \ldots \ldots \ldots$ & - & - & - & - & 149 & - & - \\
\hline Estefanurose $\quad \ldots \ldots \ldots \ldots \ldots \ldots \ldots \ldots \ldots \ldots \ldots$ & - & - & - & - & - & - & - \\
\hline Verminose $\quad \ldots \ldots \ldots \ldots \ldots \ldots \ldots \ldots \ldots \ldots \ldots$ & - & - & - & - & - & - & - \\
\hline 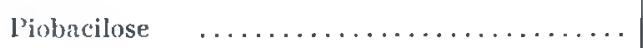 & 1 & - & 2 & - & - & - & - \\
\hline Sarcosporidiose $\quad \ldots \ldots \ldots \ldots \ldots \ldots \ldots \ldots \ldots \ldots$ & 32 & - & 62 & - & 一 & - & 114 \\
\hline$\Delta$ denite $\quad \ldots \ldots \ldots \ldots \ldots \ldots \ldots \ldots \ldots \ldots \ldots \ldots$ & 9.954 & 0,223 & $1.7 \% 4$ & $0,0-10$ & - & - & 一 \\
\hline Glossite $\quad \ldots \ldots \ldots \ldots \ldots \ldots \ldots \ldots \ldots \ldots \ldots \ldots \ldots$ & - & - & 60 & - & - & - & - \\
\hline Enfizema mesentérico $\ldots \ldots \ldots \ldots \ldots \ldots \ldots$ & - & - & - & - & - & - & - \\
\hline 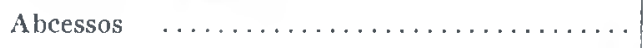 & 7.792 & 0,174 & 892 & 0,020 & 3.327 & 0,074 & - \\
\hline Côr anormal - Ictericia e adipoxantose .... & 335 & 0,007 & 327 & 0,007 & 298 & 0,006 & 275 \\
\hline Enterite $\quad \ldots \ldots \ldots \ldots \ldots \ldots \ldots \ldots \ldots \ldots \ldots \ldots \ldots$ & - & - & - & 一 & - & 一 & - \\
\hline Melanose $\quad \ldots \ldots \ldots \ldots \ldots \ldots \ldots \ldots \ldots \ldots \ldots \ldots \ldots$ & 2 & - & - & $\ldots$ & - & - & - \\
\hline Enfizema $\quad \ldots \ldots \ldots \ldots \ldots \ldots \ldots \ldots \ldots$ & - & -- & - & ' - & 433.214 & 9,705 & - \\
\hline Aspiração de sangue e alimentos $\ldots . . . . .$. & - & - & - & - & 960.876 & 21,526 & - \\
\hline Congestão $\quad \ldots \ldots \ldots \ldots \ldots \ldots \ldots \ldots \ldots \ldots \ldots \ldots$ & - & - & - & - & 16.602 & 0,372 & 1.182 \\
\hline Bronquite $\quad \ldots \ldots \ldots \ldots \ldots \ldots \ldots \ldots \ldots \ldots \ldots$ & - & - & - & - & 1.916 & 0,043 & - \\
\hline Bronquice verminótica $\ldots \ldots \ldots \ldots \ldots \ldots$ & - & - & - & - & 11.101 & 0,249 & - \\
\hline Broncopneumonia $\quad \ldots \ldots \ldots \ldots \ldots \ldots \ldots$ & - & - & - & - & 31.656 & 0,709 & - \\
\hline Pleurisia - aderências $\ldots \ldots \ldots \ldots \ldots \ldots$ & - & - & 一 & - & 2.082 & $0,04.7$ & - \\
\hline Aderências $\quad \ldots \ldots \ldots \ldots \ldots \ldots \ldots \ldots \ldots \ldots$ & - & - & - & - & - & - & - \\
\hline Gangrena $\quad \ldots \ldots \ldots \ldots \ldots \ldots \ldots \ldots \ldots \ldots \ldots$ & - & - & - & - & 1 & - & - \\
\hline Edema $\quad \ldots \ldots \ldots \ldots \ldots \ldots \ldots \ldots \ldots \ldots \ldots \ldots$ & - & - & - & - & 226 & 0,05 & - \\
\hline Miocardite $\quad \ldots \ldots \ldots \ldots \ldots \ldots \ldots \ldots \ldots \ldots \ldots$ & - & - & - & - & - & - & 3. 433 \\
\hline Pericardite $\quad \ldots \ldots \ldots \ldots \ldots \ldots \ldots \ldots \ldots \ldots \ldots \ldots$ & - & - & - & - & - & - & 72.409 \\
\hline Ylemorragia $\quad \ldots \ldots \ldots \ldots \ldots \ldots \ldots \ldots \ldots$ & - & $\ldots$ & - & -.. & 7.015 & 0,157 & 17.623 \\
\hline Cirrose $\quad \ldots \ldots \ldots \ldots \ldots \ldots \ldots \ldots \ldots \ldots \ldots \ldots \ldots \ldots$ & - & - & - & - & - & - & - \\
\hline Peri-hepatites $\quad \ldots \ldots \ldots \ldots \ldots \ldots \ldots \ldots \ldots \ldots \ldots$ & - & - & - & - & - & - & - \\
\hline Atrofia $\quad \ldots \ldots \ldots \ldots \ldots \ldots \ldots \ldots \ldots \ldots \ldots \ldots \ldots \ldots$ & - & - & - & - & - & - & - \\
\hline Tumor $\quad \ldots \ldots \ldots \ldots \ldots \ldots \ldots \ldots \ldots \ldots \ldots \ldots \ldots \ldots$ & - & - & - & - & - & - & - \\
\hline Angiomatose $\quad \ldots \ldots \ldots \ldots \ldots \ldots \ldots \ldots \ldots$ & - & - & - & - & - & - & - \\
\hline Uronef rose $\quad \ldots \ldots \ldots \ldots \ldots \ldots \ldots \ldots \ldots \ldots \ldots \ldots$ & - & - & - & - & - & - & - \\
\hline Nefrite $\quad \ldots \ldots \ldots \ldots \ldots \ldots \ldots \ldots \ldots \ldots \ldots \ldots$ & - & - & - & - & - & - & - \\
\hline Infarto anêmico $\ldots \ldots \ldots \ldots \ldots \ldots \ldots \ldots$ & - & - & - & - & 一 & - & - \\
\hline Contusão $\quad \ldots \ldots \ldots \ldots \ldots \ldots \ldots \ldots \ldots \ldots \ldots \ldots$ & 403 & 0,009 & 396 & 0,008 & - & - & - \\
\hline Degencrações $\quad \ldots \ldots \ldots \ldots \ldots \ldots \ldots \ldots \ldots \ldots$ & - & - & - & - & - & - & - \\
\hline 'I o & 369.867 & - & 289.618 & - & 1.511 .119 & - & 331.215 \\
\hline
\end{tabular}


USAS DE CONDENAÇÃO DE CABEÇAS E VISCLRAS DE SUINOS

beças abatidas $-4.463 .848-1936$ a 19.19

\begin{tabular}{|c|c|c|c|c|c|c|c|c|c|c|}
\hline$\%$ & Fígados & $\%$ & Rins & $\%$ & Intestinos & $\%$ & Baços & $\%$ & Peritônio & $\%$ \\
\hline- & 33.275 & 0,745 & 858 & 0,019 & 23.102 & 0,521 & 14.5002 & 0,325 & - & - \\
\hline- & - & - & - & - & - & - & - & - & $\cdots$ & - \\
\hline-- & - & - & 4 & $\ldots$ & 14 & - & 2.366 & 0,053 & - & - \\
\hline$\ldots$ & - & - & - & - & - & - & - & $\cdots$ & - & - \\
\hline 0,004 & 885 & 0,020 & 582 & 0,013 & 720 & 0,016 & 805 & 0,018 & - & - \\
\hline 5,286 & - & - & - & - & - & - & - & - & - & $\cdots$ \\
\hline- & 5 & - & - & -. & - & - & - & - & $\ldots$ & - \\
\hline- & 110.020 & 2,169 & 7 & $\ldots$ & - & - & 1 & - & 920 & 0,021 \\
\hline- & 431.589 & 9,668 & 72 & $\ldots$ & -. & - & - & - & - & - \\
\hline- & 949.192 & 21,264 & 1.980 .384 & 42,124 & - & - & - & - & - & - \\
\hline- & - & - & - & - & 1. 181 & 0,026 & - & - & - & - \\
\hline- & 2 & - & - & - & - & - & - & - & - & - \\
\hline 0,002 & - & - & - & - & - & - & - & - & - & - \\
\hline- & 6 & $\cdots$ & - & - & - & - & - & - & - & - \\
\hline- & - & - & - & - & - & - & - & - & - & - \\
\hline- & - & - & - & -- & 5.516 & 0,168 & 36 & - & - & - \\
\hline- & 50.720 & 1,136 & 37.930 & 0,850 & 3.017 & 0,068 & - & - & - & - \\
\hline $0 ; 006$ & 101.368 & 2,271 & 144.963 & 3,247 & 221 & 0,005 & 235 & 0,005 & - & - \\
\hline- & - & -- & - & - & 522 & 0,012 & - & $\cdot-$ & - & - \\
\hline- & - & - & $\cdots$ & - & - & - & - & - & $\ldots$ & - \\
\hline- & - & $\cdots$ & - & - & - & - & - & & $\ldots$ & - \\
\hline- & - & - & - & - & - & - & - & & . & - \\
\hline 0,026 & 81.678 & 1,830 & 49.590 & 1,111 & - & - & 169 & 0,0013 & $\ldots$ & - \\
\hline- & - & - & - & - & - & - & - & $\cdots$ & . & - \\
\hline- & - & - & $\cdots$ & - & - & -- & - & $\cdots$ & $\ldots$ & - \\
\hline- & - & - & - & $\cdots$ & - & $\cdots$ & - & - & - & - \\
\hline- & - & - & - & - & - & $\cdots$ & $\cdots$ & $\cdots$ & - & - \\
\hline- & 1.342 & 0,030 & - & - & - & - & - & $\cdots$ & -.- & - \\
\hline- & - & - & - & - & - & $\cdots$ & -- & - & $\ldots$ & - \\
\hline- & - & - & - & - & - & - & $\cdots$ & - & 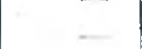 & -. \\
\hline 0,077 & - & - & - & - & -- & $\cdots$ & $\cdots$ & - & .. & \\
\hline 1,622 & - & - & - & - & -. & - & & $\therefore$ & . & - \\
\hline 0,395 & 6.799 & 0,152 & $r_{2}$ & $\ldots$ & -. & - & $\ldots$ & - & $\ldots$ & 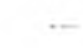 \\
\hline- & 79.701 & 1,785 & - & -- & - & $\cdots$ & $\cdots$ & - & 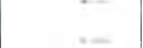 & - \\
\hline- & $116.8 \% 2$ & 2,617 & - & - & $\ldots$ & -- & $\cdots$ & & - & * \\
\hline- & 586 & 0,013 & 2.011 & $0,0.16$ & - & $\cdots$ & $\cdots$ & - & -. & - \\
\hline- & 3 & - & - & -- & - & - & . & -. & $\ldots$ & .. \\
\hline- & 478 & 0,011 & - & - & - & - & $\cdots$ & - & - & - \\
\hline- & - & - & 509.265 & 11,109 & - & - & - & - & $\ldots$ & - \\
\hline- & - & - & 775.758 & 17,379 & - & - & - & - & - & - \\
\hline- & - & - & 3.406 & 0,076 & - & - & $\cdots$ & - & - & - \\
\hline- & - & - & - & - & - & - & - & - & - & - \\
\hline - & 8.416 & 0.190 & 1.903 & $0,0.13$ & - & - & $\cdots$ & - & - & - \\
\hline- & 1.972907 & - & 3.406 .835 & - & 36.593 & - & 18.117 & - & 920 & - \\
\hline
\end{tabular}





\section{$\operatorname{DISCUSSAO}$}

0 quadro I refere-se aos totais, às percentagens de incidência e ao destino dado às carcaças, segundo a extensão com que se apresentaram as várias causas de rejeiçăo.

Verifica-se, por êsse quadro, que $10,425 \%$ do total de suínos abatidos nesses 14 anos apresentaram as várias causas de rejeição; no entretanto, pelo quadro II, verifica-se que sòmente $8,081 \%$ foram retirados do consumo como carne fresca, sendo os restantes $2,344 \%$ dados ao consumo sem tratamento algum, pois que as causas de rejeição se apresentaram num tal estado evolutivo ou de tal forma localizadas, que as carnes não ofereciam perigo à saúde humana.

No quadro I deve-se ainda notar a percentagem de incidência da cisticercose em carcaças $(6,362 \%)$, assim como da tuberculose $(2,285 \%)$ e das mortes em vagões e currais $(0,495 \%)$.

As outras causas de rejeição de carcaças de suínos não oferecem interèsse especial, em razáo de sua baixa percentagem de incidência em matadouro; deve-se, entretanto, observar que a peste suína não aparece aqui com percertagem alta, embora cause não pequenos prejuizos à pecuária nacional, de vez que os animais atacados sucumbem antes de serem enviados ao matadouro.

0 quadro II refere-se às principais causas de rejeiŗão en geral, de carcaças, incluindo-se nesses números as condenadas, as destinadas à banha, à salga e à conserva. Por êsse quadro verifica-se que $8,081 \%$ dos animais abatidos nesse período foram retirados do consumo como carne fresca, com um total de 360.787 carcaças, somando $25.255 .090 \mathrm{~kg}$. Verifica-se, ainda, que $4,831 \%$ (215.667 carcaç‘s, com $15.096 .690 \mathrm{~kg}$ ) foram aproveitados para fabricação de banha (logo, a carne foi retirada do consumo como carne fresca) e $0,990 \%$ $(44.213$ carcaças com $3.094 .910 \mathrm{~kg}$ ) foram condenadas; essas duas parcelas somadas dão um total de 259.880 carcaças, o que corresponde a $18.191 .600 \mathrm{~kg}$ de carne e gordura totalmente subtraídós ao consumo, isto é, $5,821 \%$ do total de animais abatidos.

() quadro III reune as quatro principais causas da retirada de carcaças do consumo em estado fresco. Nota-se que a cisticercose acarretou rejeição em percentagem várias vêzes maior que tôdas as outras causas reunidas. Assim, enquanto é ela responsável por $72,055 \%$ das carcaças retiradas do consumo como carne fresca, a tuberculose só o é por $12,835 \%$, e as más condiçōes de transporte (representadas pelos animais chegados mortos, mortos nos currais e contundidos), por $9.502 \%$; a cisticercose foi causa de retirada do consumo como carne fresca, de $5,824 \%$ do total abatido, enquanto a tuberculose só o foi em $1,037 \%$ dêsse total, e as más condições de transporte, em $0,768 \%$. 
O quadro IV é um resumo das principais causas de condenação de carcaças. Vimos, pelo quadro I, que foram condenadas 44.213 carcaças; pelo qua. dro IV observa-se que:

1) - dêsse total, $50,016 \%$, isto é, 22.114 carcaças, com $1.547 .980 \mathrm{~kg}$, foram condenadas por terem os animais chegado mortos on terem sucumbido nos currais, vítimas principalmente das más condições de transporte;

2) - a tuberculose foi causa de condenação de 15.216 carcaças, com $1.065 .120 \mathrm{~kg}$, isto é, $33,962 \%$ das carcaças condenadas;

3) - a cisticercose foi responsável pela condenação de 2.708 carcaças. com um total de $189.560 \mathrm{~kg}$, isto é, $6,125 \%$ do total condenado;

4) - as colorações anormais, principalmente icterícia e adipoxantose, entraram com um total de 2.285 carcaças, que perfazem $159.950 \mathrm{~kg}$, ou sejam, $5,168 \%$ das carcaças condenadas.

$\mathrm{O}$ quadro $\mathrm{V}$ trata das carcaças destinadas à fabricação de banha.

Verifica-se pelo quadro I que foram aproveitadas condicionalmente para fabricação de banha nada menos que 215.667 carcaças; pelo quadro $\mathrm{V}$ observa-se que:

1) - 184.665 carcaças, com $12.926 .550 \mathrm{~kg}$, ou sejam, $85,625 \%$ das carcaças destinadas à banha, o foram por cisticercose;

2) - 18.396 carcaças, com $1.287 .720 \mathrm{~kg}$, ou sejam, $8,530 \%$ do total des. tinado à banha, o foram por tuberculose;

3 - as outras importantes causas de aproveitamento para banha foram as contusões $(2,373 \%)$, os abcessos $(1,710 \%)$ e as peritonites $(0,949 \%)$.

O quadro VI resume as principais causas de aproveitamento de carcaças para fabricação de conservas. Ainda aqui observa-se a preponderante percentagem de cisticercose $(61,003 \%)$ sôbre as outras causas; segue-se a tuberculose, com $19,704 \%$, a brucelose, com $7,162 \%$ e as contusōes, com $4,056 \%$. Tais per. centagens referem-se ao total de carcaças destinadas à fabricação de conservas.

$O$ quadro VII enumera as três principais causas de aproveitamento de carcaças, condicionado à salga. Nota-se que a cisticercose distancia-se muito de qualquer outra causa, com $82,16 \%$ do total destinado à salga, seguida pelas contusões, com $8,93 \%$, e pela tuberculose, com $5,93 \%$. 
O destino das cabeças e vísceras rejeitadas, não varia, como o que se dá com as carcaças; elas, quando anormais, não são aproveitadas para alimentação humana, sendo condenadas para graxaria industrial. Essa razão, associada a outras expostas em trabalho anterior, como o fato de serem elas examinadas à parte e muitas vêzes condenadas sem que a carcaça o seja, nos fez cuidar delas em separado. Assim, no quadro VIII, estão enumeradas as várias causas de condenaçōes de cabeças e de vísceras, assim como as respectivas percentagens de incidência.

Julgamos interessante tecer algumas considerações sôbre as rejeições de vísceras (quadro VIII). Inicialmente, convém notar que, dos órgãos condenados, numèricamente, os rins situam-se em primeiro plano, com um total de 3.406 .835 peças $(76,320 \%$ do total abatido), dos quais, $12,124 \%$ por estefanurose, $17,379 \%$ por nefrites, $11,409 \%$ por uronefrose e $3,247 \%$ por apresentarem coloraçōes anormais, principalmente icterícias e adipoxantoses.

Foram condenados 1.972 .907 fígados (44,197\% do total abatido), dos quais $21,264 \%$ por estefanurose, $9,668 \%$ por hidatidose, $2,617 \%$ por peri-hepatites e 2,569\% por presença de Cysticercus tenuicolis.

Grande foi também o número de pulmões condenados, atingindo 1.511.119 unidades $(33,852 \%$ do total abatido), dos quais $21,526 \%$ por terem os animais aspirado sangue e alimentos no período agônico e 9,705\% por apresentarem enfisema. E' interessante observar que, no referente ao Metastrongilus salmi, Matos encontrou, no Frigorífico Armour, de São Paulo, percentagem de 62,5\% de incidência, sôbre 817 pulmões examinados.

Com relação às cabeças, línguas e corações, foram a cisticercose e a tuberculose, as principais causas de rejeição, atingindo a primeira, em cabeças, a percentagem de $5,627 \%$, em línguas $5,369 \%$ e em coraçōes $5,286 \%$, ao passo que a tuberculose incidiu sôbre $2,226 \%$ das cabeças e $1,019 \%$ das línguas.

Quanto aos intestinos e baços, foi a tuberculose a principal causa de rejeição, incidindo sôbre 0,524\% dos primeiros e 0,325\% dos segundos.

Nota-se, portanto, terem sido quatro as principais doenças parasitárias causadoras de rejeição de vísceras de suínos nesta regiâo brasileira, no período estudado:

1) Cisticercose (Cysticercus cellulosue), larva da Tênia solium.

2) Hidatidose, larva do Echinococcus granulosus.

3) Estefanurose (Stephanurus dentatus).

4) Cysticercus tenuicolis, larva da Tênia hidatigena 
Das moléstias infectuosas, a qus maior percentagem de incidência revelou em matadouro, foi a tuberculose.

Como causa importante de condenação de carcaças, citamos as más condiçöes de transporte, representadas por animais contundidos, chegados mortos e mortos nos currais.

Nas tabelas e gráficos seguintes, apresentamos a evolução percentual dessas seis causas de rejeição, de 1936 a 1949.

TABELA I - PERCENTAGENS DE INCIDENCIA EM CARCAÇAS DA

CISTICERCOSE (C. collulosae), TUBERCULOSE E MAS CONDIÇOLS DE

TRANSPORTE, SÔBRE 4.463 .848 SUfNOS ABATIDOS DE 1936 A 1949

\begin{tabular}{|c|c|c|c|}
\hline$A \cap \circ s$ & $\begin{array}{l}\text { Cisticercose } \\
(C . \text { cellulosae }) \\
(\%)\end{array}$ & Tuberculose $(\%)$ & $\begin{array}{l}\text { Más condições de transporte } \\
\text { (contundidos, chegados mortos } \\
\text { e encontrados mortos) }(\%)\end{array}$ \\
\hline 1936 & 6,199 & 3,166 & 0,188 \\
\hline 1937 & 7,411 & 2,789 & 0,433 \\
\hline 1938 & 6,841 & 2,814 & 0,308 \\
\hline 1939 & 6,995 & 2,926 & 0,747 \\
\hline 1940 & 6,550 & $2,4,96$ & 0,710 \\
\hline 1941 & 5,920 & 2,973 & 0,721 \\
\hline 1942 & 8,123 & 3,612 & 1,104 \\
\hline 1943 & 6,779 & 2,454 & 0,730 \\
\hline 1.944 & 6,059 & 2,323 & 0,739 \\
\hline 1945 & 5,687 & 1,985 & 0,844 \\
\hline 194.6 & 5,008 & 1,644 & , 1,730 \\
\hline 1947 & 6,195 & 1,564 & 0,970 \\
\hline 1948 & 6,147 & 1,052 & 0,840 \\
\hline 1949 & 6,163 & 0,778 & 0,740 \\
\hline
\end{tabular}




\section{GRÁFICOI}

GRÁFICO DA PORCENTAGEM DE IMCIDÊMCIA(EM CARCACAS)DA CIS. TICERCÓSE SUINA (C.CELLULOSA), DA TUBERCULOSE E DAS MORTES EM TRANSPORTES E EM CURRAIS,SOBRE 4.463.848 AMIMAIS ABATIDOS - 1936 a 1949.

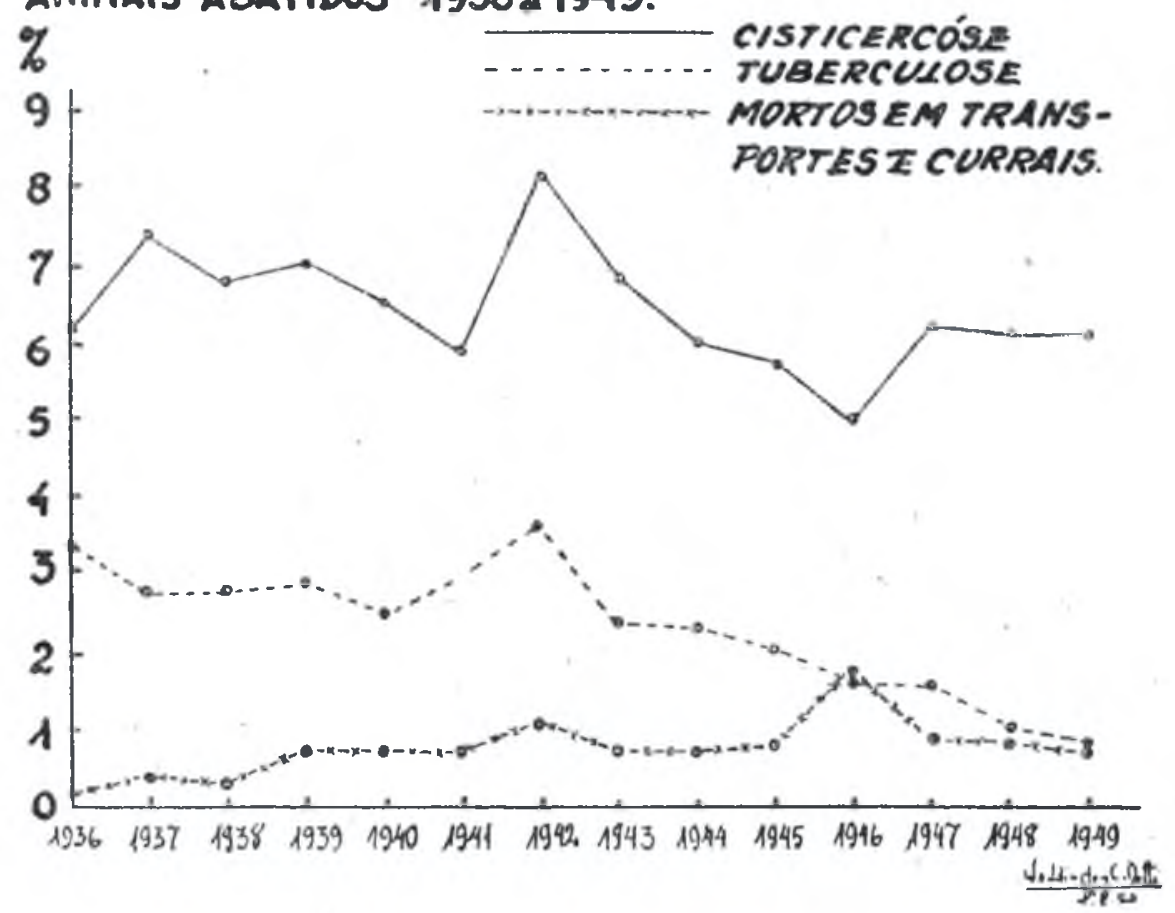


'IABELA II - PERCEN'IAGENS DE INCIDENCIA DA CISTICERCUSE

(C. cellulosae) EM CABWCAS, IINGUAS H CORAÇOES

(Percentagens calculadas sôbre 4.463.848 suínos abatiklos de 1936 a 1949)

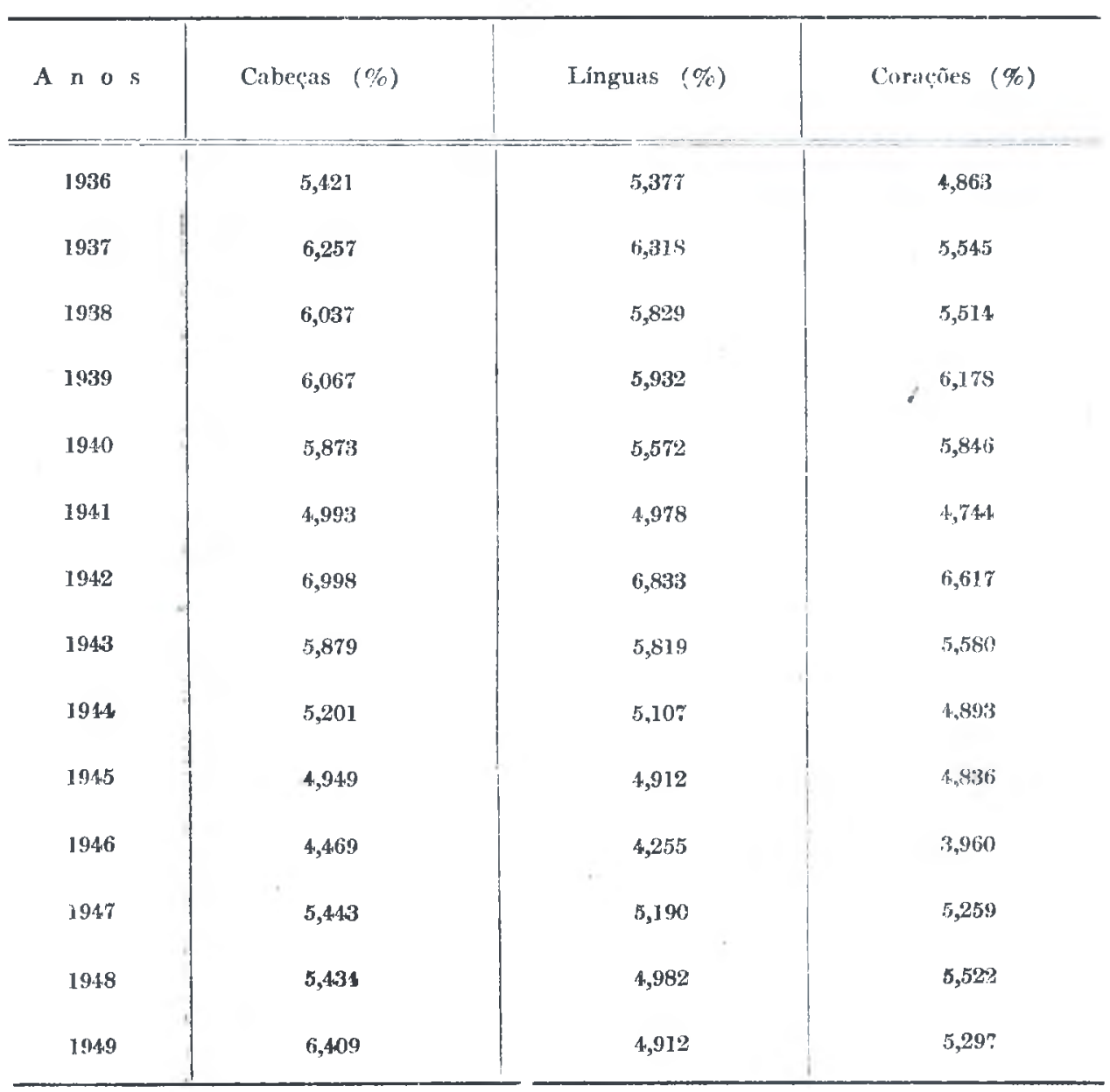




\section{GRAFICOL}

\section{GRÁFICO DA DORCENTAGEM DE INCIDÊNCIÁ DA CISTICERCÓSE (C.CELLULOSE) EM CABEGAS, LIMGUAS E CORAFÖRS, SOBRE 4.463.848 ANIMAIS ABATIDOS - 1936 a 1949.}

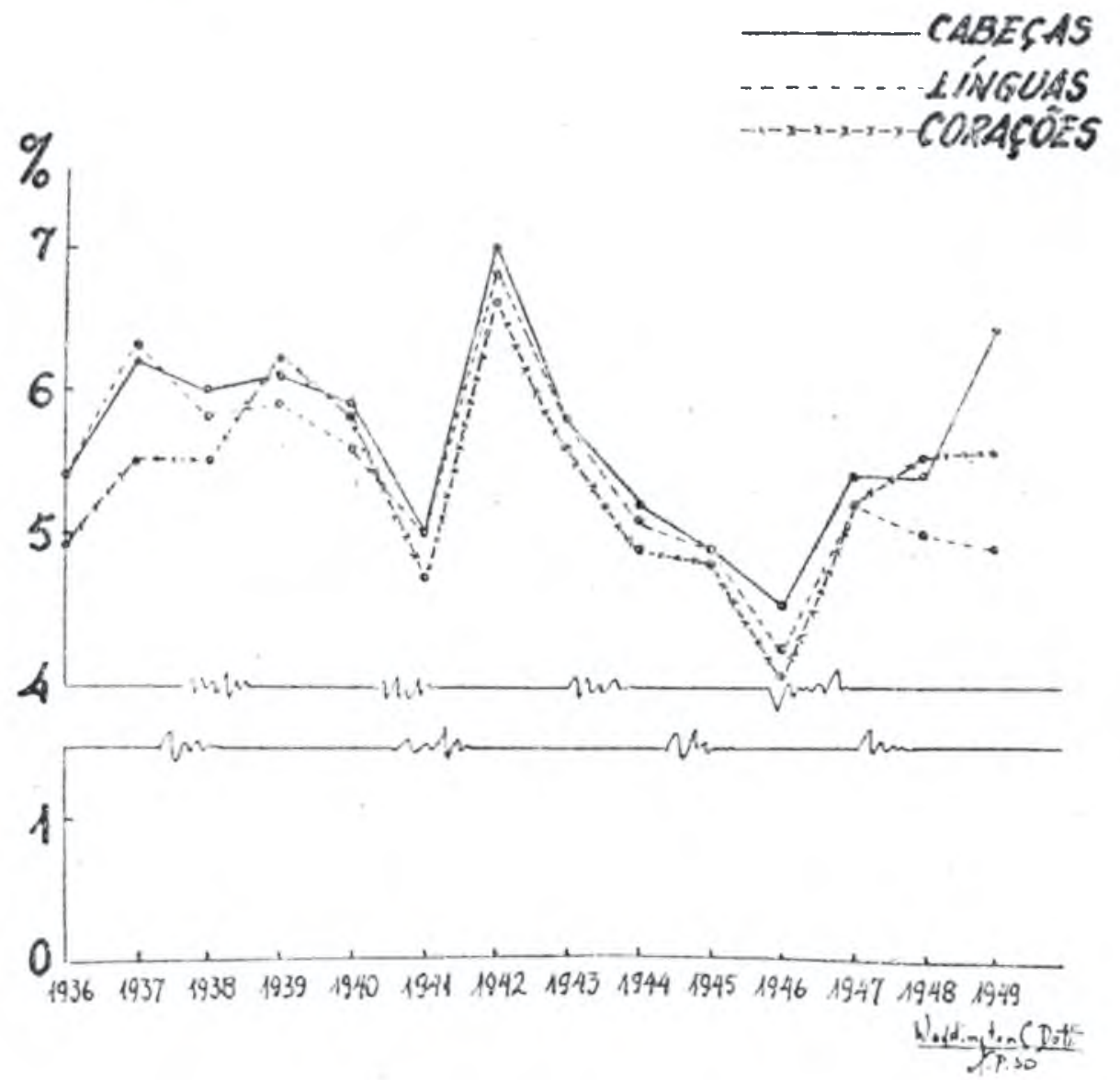


TABELA III - PERCENTAgens DE INCIDENCIA DA TUberCUlOSE FM

Cabeças, lfnguas, pUlmóes e ffGados, SObRe 4.463.848 SufNos ABATIDOS DE 1936 A 1949

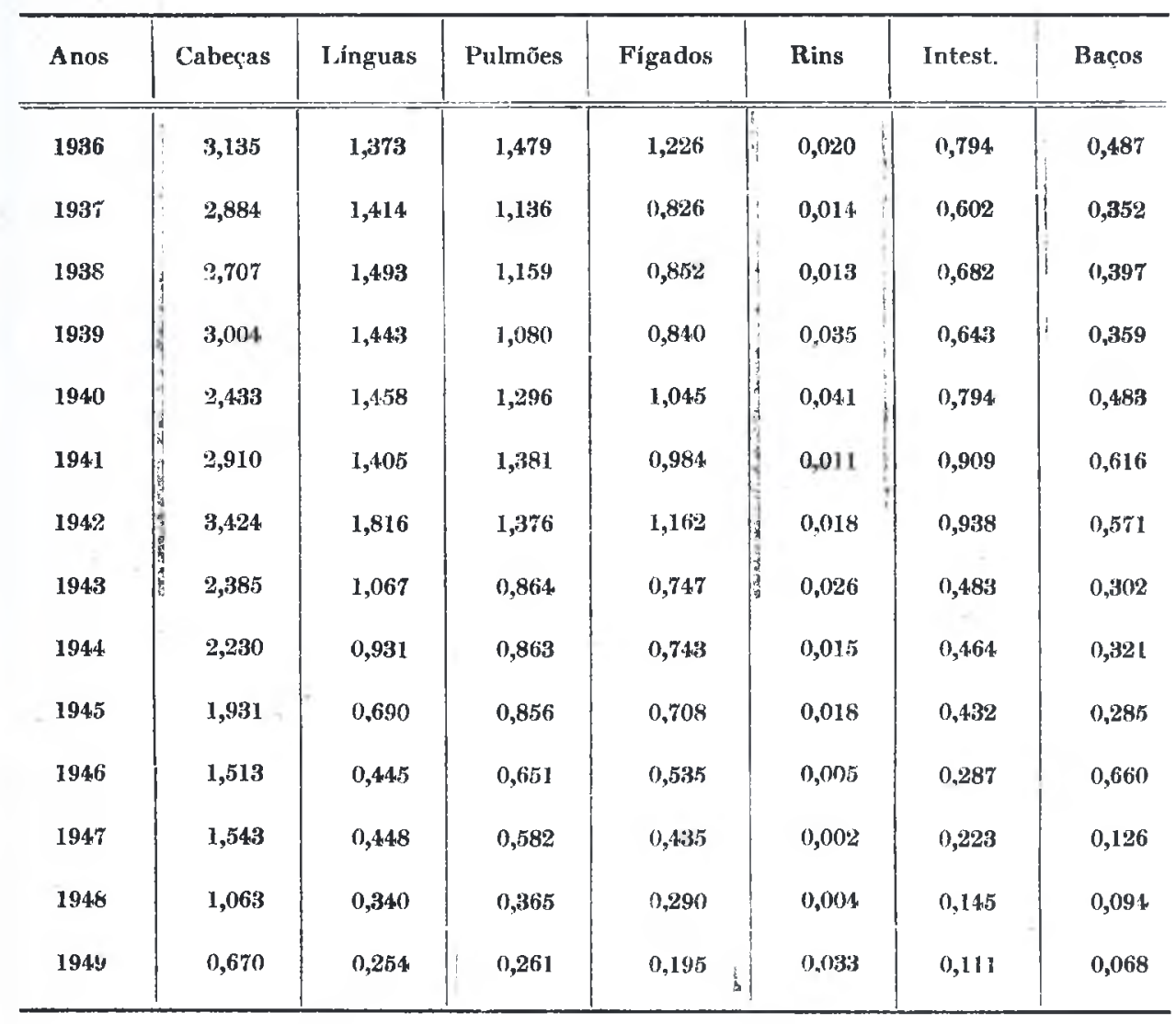




\section{GRAFICO III}

GRÁFICO DA PORCENTAGEM DE INCIDENCIA DA TUBERCULOSE SUINA EM CABECAS, LINGUAS, PULMÖESE FÍGADOS, SOBRE 4.463.848 ANIMAIS ABATIDOS.

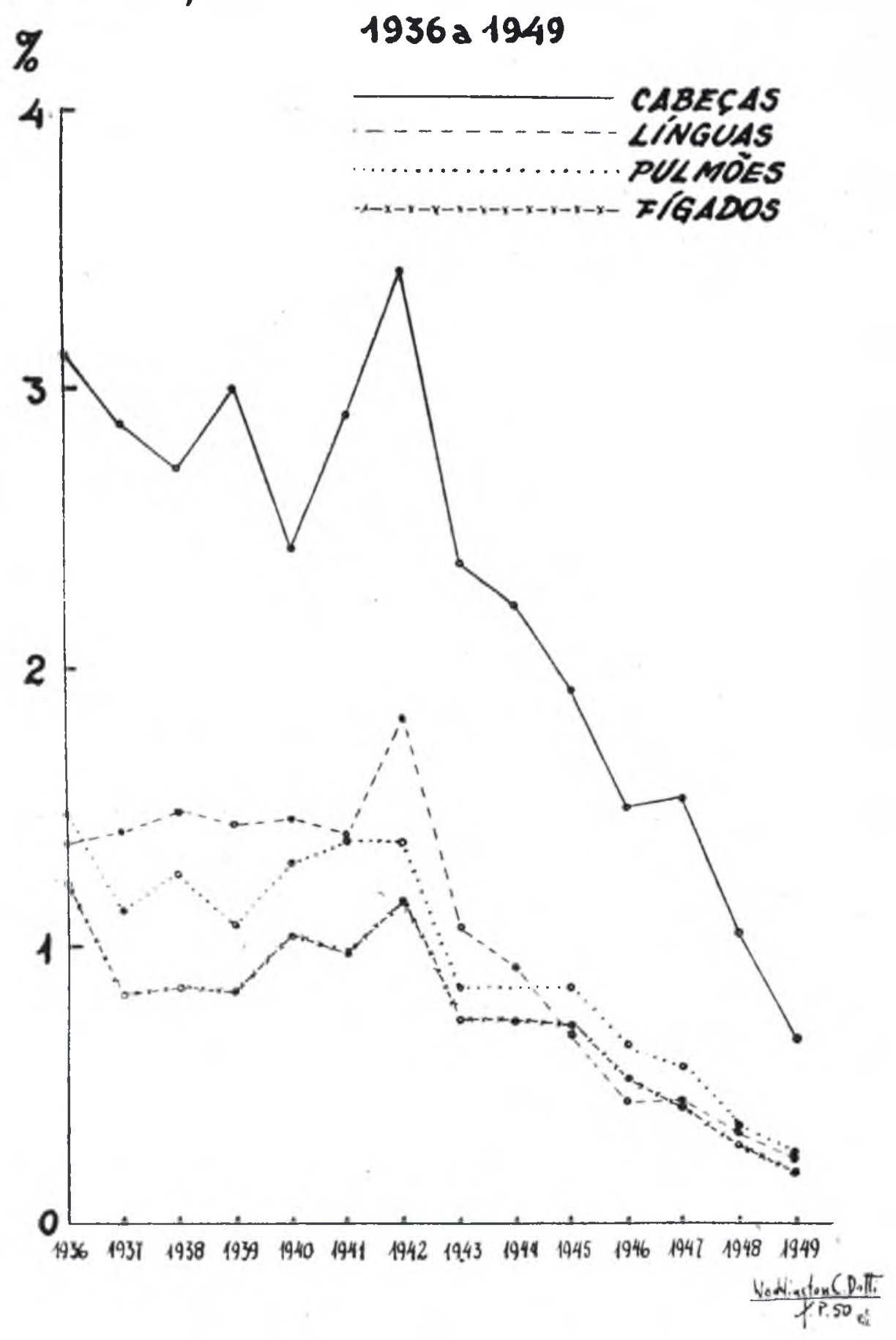


TABEla IV - PERCENTAgens De INCIDenCIA DO CYSTICERCUS TENUICOLIS EM FIGADOS, SOBRE 4.463.848 SUINOS AB'TIDOS DE 1936 A 1949

\begin{tabular}{c|c}
\hline A n o s & P e r c e t a g e s \\
\hline 1936 & 1,119 \\
1937 & 0,784 \\
1938 & 1,240 \\
1939 & 0,634 \\
1940 & 1,889 \\
1941 & 4,049 \\
1942 & 5,542 \\
1943 & 3,448 \\
1944 & 2,531 \\
1945 & 2,552 \\
1946 & 2,543 \\
1947 & 3,068 \\
1948 & 2,882 \\
194.9 & 2,362 \\
& \\
\hline
\end{tabular}

\section{GRAFICO IR}

GRÁFICO DA PORCENTAGEM DE INCIDÊNCIA DO CYSTICERCUS TENUICOLIS EM FIGADOS DE SUINOS, SOBRE 4.463 .848 ANIMAIS ABATIDOS.
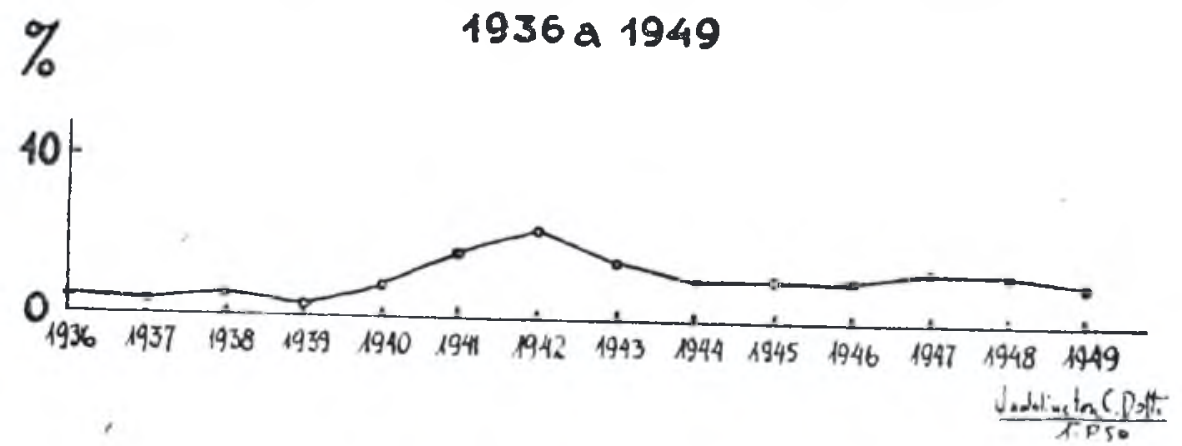
TABELA $V$ - PERCENTAGENS DE INCIDENCIA

DA HIDATIDOSE EM FIGADOS, SOBRE 4.463.848 SULNOS ABATIDOS DE 1936 A 1949

\begin{tabular}{c|c}
\hline A n o s & Percentage n s \\
\hline 1936 & 11,489 \\
1937 & 9,866 \\
1938 & 9,349 \\
1939 & 7,975 \\
1940 & 8,760 \\
1941 & 8,789 \\
1942 & 12,977 \\
1943 & 12,663 \\
1944 & 11,867 \\
1945 & 11,131 \\
1946 & 8,205 \\
1947 & 8,649 \\
1948 & 7,204 \\
1949 & 6,507 \\
\hline
\end{tabular}

\section{GPÁFICO P}

GRÁFICO DA PORCENTAGEM DE INCIDÊNCLA DE HIDATIDOSE EM FÍGADOS DE SUÍNOS, SOBRE 4.463 .848 ANIMAIS ABATIDOS-1936 a 1949.

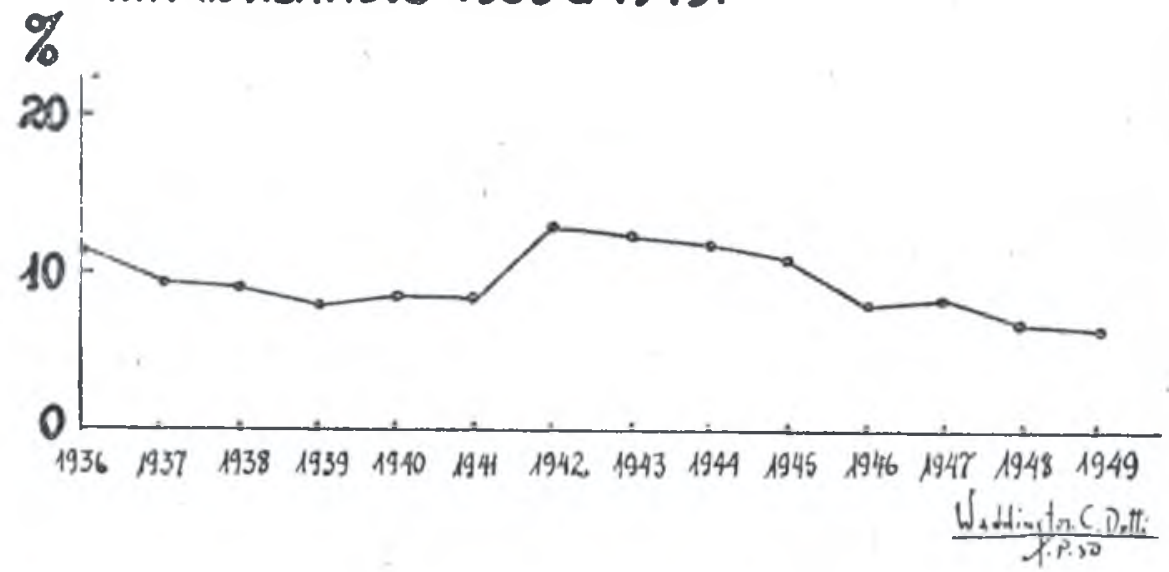


TABELA VI - PERCENTAGENS DE INCIDeNCIA DA ESTEFANUROSE (Stephanurus dentatus Diesing, 1839.) EM FfGADOS E RINS, SOBRE 4.463.848 SUINOS ABA'TIDOS DE 1936 A 1949

\begin{tabular}{c|c|c}
\hline A $n \circ s$ & $F i g$ a $\circ \mathrm{s}$ & $\mathrm{R} i \mathrm{n}$ \\
\hline 1936 & 19,215 & 45,203 \\
1937 & 18,304 & 41,328 \\
1938 & 21,246 & 37,151 \\
1939 & 24,365 & 41,785 \\
1940 & 24,930 & 60,146 \\
1941 & 24,487 & 56,962 \\
1942 & 30,979 & 65,991 \\
1943 & 25,829 & 46,646 \\
1944 & 23,071 & 43,279 \\
1945 & 19,669 & 38,213 \\
1946 & 18,591 & 31,167 \\
1947 & 17,759 & 30,522 \\
1948 & 14,174 & 27,729 \\
1949 & 16,427 & 29,009 \\
\hline
\end{tabular}




\section{GRAFICO II}

GRÁFICO DA PORCENTAGEM DE INCIDÊNCIA DA ESTEFANURÓSE (STEPHANURUS DENTATUS) EM RINS E FÍGADOS, SOBRE 4.463.848 ANIMAIS ABATIDOS- 193621949

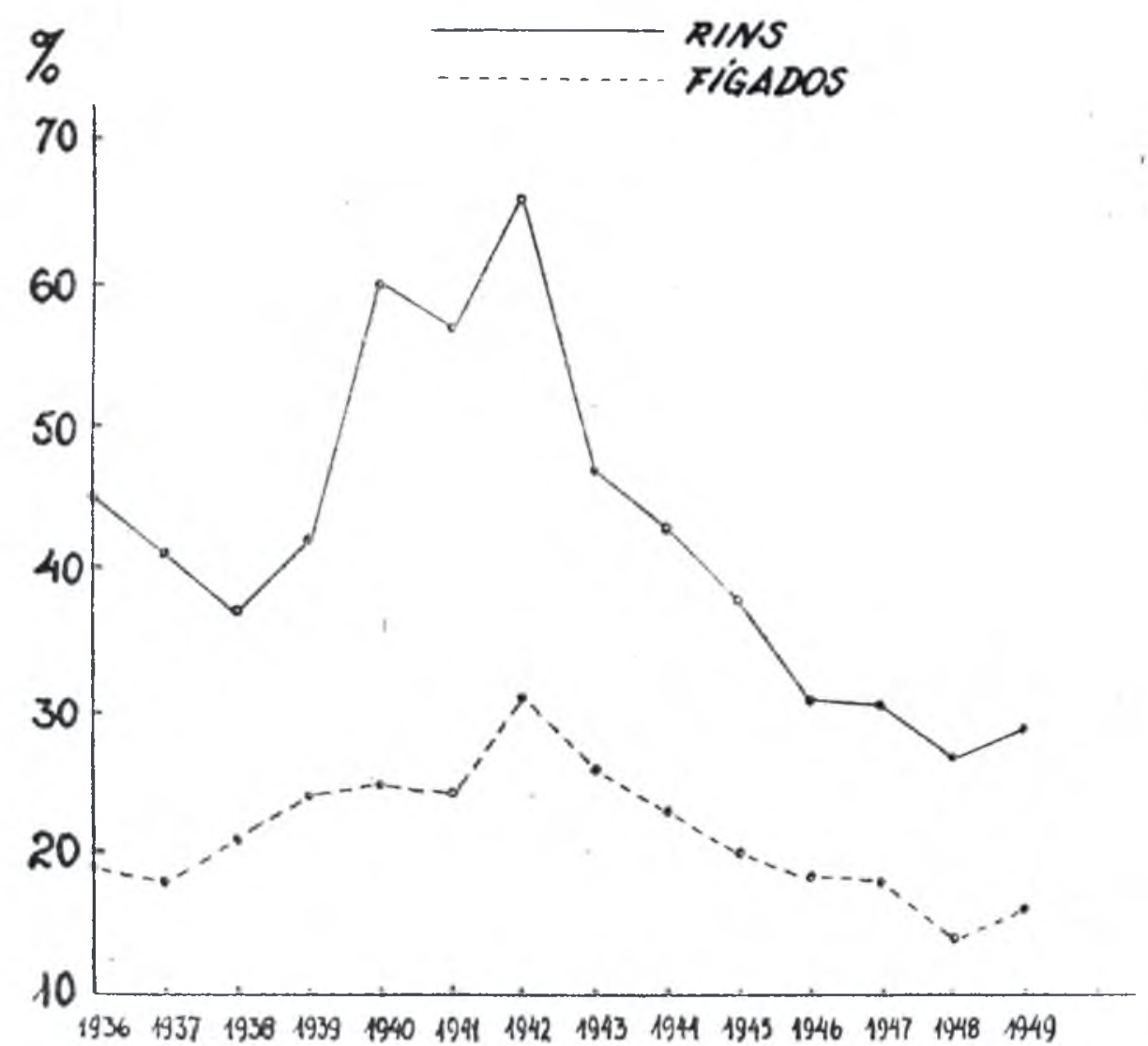

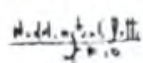


Analisando as tabelas e os gráficos, podemos concluir:

\section{Tabela I Gráfico I}

1) - A cisticercose (C. cellulosae) apresentou aproximadamente a mesma percentagem de incidência em carcaças (cêrca de 6\%), nos anos de 1936, 1947, 1948 e 1949, variando para mais nos anos de 1937 e 1942, e para menos nos anos de 1945 e 1946.

2) - A percentagem de incidência da iuberculose em carcaças manteve-se ao redor de $3 \%$ no início do período estudado, para subir a 3,6\% em 1942; a partir dêsse ano, entretanto, verificou-se constante decréscimo na incidência desta moléstia, até atingir menos de 1\%, em 1949.

3) - As más condições de transporte, reveladas, quer por animais contundidos, quer por outros chegados mortos e mortos nos currais, mantiveram-se ao redor de $0,75 \%$, durante todo o período estudado.

\section{Tabela II - Gráfico II}

1) - A percentagem de incidência da cisticercose ( $C$. cellulosae), em cabeças, línguas e corações, manteve-se ao redor de $5 \%$, variando para mais no ano de 1942 e para menos em 1946.

2) - A percentagem de incidência da cisticercose, em cabeças, línguas e corações, manteve-se pràticamente inalterada.

\section{Tabela III - Gráfico III}

1) - Observa-se sensível tendêncía ao decréscimo na incidência da tuberculose, não só em carcaças, mas também em cabeças, línguas, pulmões, fígados, intestinos e baços; excetuam-se os rins, em cujo órgão foi flutuante a percentagem de incidência. Não organizamos gráfico da percentagem de incidência da tuberculose em rins, mas sòmente referimos a sua média, citada no quadro VIII.

\section{Tubela $I V-$ Gráfico $I V$}

A percentagem de incidência do Cysticercus tenuicolis oscilou ao redor de 1\%, até 1940. De 1941 a 1942, houve sensivel aumento, ao ponto de atingir $5,54 \%$. De 1944 a 1949, tal percentagem de incidência manteve-se ao redor de $2,5 \%$. 


\section{Tabela $V$ - Gráfico $V$}

A percentagem de incidência da hidatidose em fígados de suínos, bein alta em 1936 (11,49\%), baixou nos anos seguintes até 1941 (8,79\%), para subir novamente em $1942(12,97 \%)$ e manter-se alta até $1945(11,13 \%)$; dêsse ano até 19.49 baixou novamente, mantendo-se ao redor de $7.5 \%$.

\section{Tabela VI -- Gráfico VI}

A percentagem de incidência da estefanurose (Stephanurus deniatus) em rins variou bastante, de 45,20\% em 1936 a $65,99 \%$ em 194,2 e $29,00 \%$ em 1949; o gráfico apresentado é bem elucidativo, revelando uma queda de 1936 a 1938. seguida de um aumento que permaneceu até 1942; êste aumento, entretanto, foi decrescendo a partir dêsse ano até 1948, quando então verificou-se breve acréscimo.

A percentagem de incidência da estefanurose hepática (Stephanurus dentatus) aumentou até 1942, quando baixou gradativamente até 1948 para então so. frer novo aumento.

Interessante será comparar a incidência das quatro mais importantes parasitoses (cisticercose, hidatidose, estefanurose e Cysticercus tenuicolis) no nosso, com a observada em outros países. Comecemos pela cisticercose ( $C$. cellulosae), parasitose que, pela alta percentagem de incidência e pela extrema importância que apresenta não só em relação à suinocultura como à saúde pública, está a exigir a majs vigorosa campanha de erradicação.

Vil,joen, Enelman, Brumpt, Lobato Valle e Assis Ribeiro, seja louvan do-se em trabalhos de outros autores, seja baseando-se em observações próprias, apresentam percentagens de incidência do $C$. cellulosae em várias regiōes do globo, pelas quais se infere ser pràticamente nula a incidência dessa parasitose na Inglaterra, Suíça, Dinamarca, Alemanha, Austria, Holanda, Bélgica, França e Itúlia, ao passo que em certas regiōes da Rússia foi observada incidência de $19,47 \%$; segue-se a Lituânia com $7 \%$, a Hungria, em que as percentagens variaram de 0,60 a $3,91 \%$, a Rumânia, com $0,77 \%$, a Polônia com $0,38 \%$, a Espanha com $0,29 \%$ e Portugal com 0,21\%. Relativamente aos países asiáticos, as mais altas incidências citadas referem-se à fndia, onde, em Madras e Coimbatore foram encontradas percentagens de $50 \%$ de infestação; em seguida vêm as Indias Ocidentais Holandêsas, com percentagens variando de 2 a $33 \%$, conforme a regiāo, o Japão com média de $1 \%$ de infestação e a Indochina Fran- 
cêsa, em que foi observada incidência média de $0,33 \%$; na China, nos matadouros em que há serviço organizado de inspeção, a incidência é nula.

Estudos referentes à Oceania relatam ainda não ter sido observado caso algum de cisticercose suína na Austrália e na Nova Zelândia.

VILJoen (1939), estudando a incidência da cisticercose suína em 60 matadouros da África do Sul, encontrou percentagens variáveis de 0,5 a $25 \%$, citando como regiôes mais infestadas o Senegal $(25,07 \%)$, Ficksburg $(25 \%)$, Lichtenburg $(19,48 \%)$, Potchefstroom $(15,3 \%)$ e Bethlem (11,49\%); afirma que, frente a estas percentagens, é a África do Sul a regiāo do globo mais infestada pela cisticercose suína.

Brumpt, sôbre 38.510 suínos examinados em Pretoria, encontrou 9,6\% de incidência; em Johanesburg, sôbre 343.177 suínos, observou incidência de $9.42 \%$. No Transvaal, a incidência dessa parasitose em suínos variou de 1,04 a $19,48 \%$, conforme a regiāo. Em Madagascar observaram-se incidências variando entre 4 e $20 \%$, de acôrdo com as regiōes.

Das Américas, o Canadá e os Estados Unidos apresentam incidência pràticamente nula; no Panamá, entretanto, já foi observada incidência de 15\% que, em razão de eficiente campanha de erradicação, baixou a $5 \%$; na América do Sul, encontramos o Chile com $3,60 \%$, a Venezuela com $4,10 \%$, e certas regiōes brasileiras como os Estados de São Paulo, Paraná, Santa Catarina, Minas Gerais, Mato Grosso e Goiás, cuja média atual de infestação é de 6,36\%. Lobato VAlLe assinala que, no Estado do Paraná, sôbre 55.865 suínos abatidos de agôs. to de 1929 a julho de 1930 , observou incidências que variaram de 2 a $15 \%$, conforme a cidade de onde provieram os animais; conclui o autor serem as cidades de Caeté $(15 \%)$, Quatiguá $(12,75 \%)$, Iratí $(11,26 \%)$, Boa Esperança e Piraí (ambas com 10\%), as mais infestadas. Sendo êsse Estado um dos gran. des fornecedores de suínos aos matadouros e frigoríficos do Brasil Central, acreditamos serem os animais dêle provindos, responsáveis, em grande parte, pela alta incidência por nós encontrada.

Em trabalho anterior (1949), observamos que, nos anos de 1946 e 1947, a cisticercose suína atingiu alta percentagem de incidência (média de 6\%), nos estabelecimentos abatedores situados no Brasil Central. Pelo trabalho atual, em que estamos apresentando elementos referentes ao longo período de 1936 a 1949 , nota-se nãc ter havido alteração sensível nessa percentagem. Como, na região em estudo, foram abatidos suínos provenientes não só do Brasil Central, mas, também, e em grande número, de Estados circunvizinhos, e levando-se em conta que as percentagens por nós relatadas referem-se sòmente a aproximadamente $50 \%$ dos suínos abatidos na região, acreditamos que o Brasil Central, assim co- 
mo as regióes fornecedoras de suínos a esta, situam-se, no mundo, entre as altamente parasitadas. Sendo esta doença reflexo da mais absoluta ignorância de rudimentares princípios de higiene, é de julgar-se o nível sanitário em que se encontram nossas populações rurais. Cabe aqui elogio aos infatigáveis defensores anônimos da saúde pública, que são os veterinários inspetores que trabalham junto aos nossos matadouros, frigoríficos e charqueadas; são êles que, cortando o ciclo evolutivo desta malfadada parasitose, impedem que tal doença, que tantos prejuizos nos tem causado, quer pela condenação de grande quantidade de carcaças, quer pela sua localização tanto adulta como larvar na espécie humana, atinja níveis mais altos que os atuais.

\section{HIDATIDOSE}

Com referência a esta zoonose, moléstia parasitária também de incidência quase universal, as consideraçōes sôbre os prejuizos causados à saúde pública e à economia nacional, não sáo menos importantes que as relativas à cisticercose.

O cisto hidático, forma larvar do Echinococcus granulosus (BATsch, 1786) é, tanto do ponto de vista econômico como sanitário, muito mais importante que a forma adulta, parasita das primeiras porçōes do intestino delgado do cão doméstico e de alguns carnívoros selvagens.

Davis, citando MACKıE, apresenta a distribuição da hidatidose por continentes e países, em 1945:

Africa - Algéria*, Tunísia, Libéria, Egito*, Abissinia, Colônia do Cabo*.

Ásia - Palestina e Síria*, Norte da China. Mongólia, Japão, Tonquim Filipinas, Sibéria, Arábia, India (Punjab).

Austrália - Sul da Austrália*, Tasmânia*, Nova Zelândia*.

Europa - Central* e do Norte.

América do Norte - Ocasional.

América do Sul -- Argentina*, Chile, Uruguai* Paraguai*.

Na Itália, Putzu, citando Giovanni (1907), apresenta freqüências de $20 \%$ nos ovinos e $10 \%$ nos bovinos. Cita ainda Businco e Padronerti, que encon-

A indicação * significa alta percentagem de incidencia no homem. $W^{\prime}$ eviclente ser incompleta esta relação, de vez que deixaram de ser citadas áreas importantes de in festação desta parasitose, como o sul do Brasil e o Perú, nas quais a alta incidẻncia do parasita é de há muito conhecida (C. Pinto, Almeida, Pereira, Meneghetti, Mesquita Barbosa, Saco). 
traram, na Úmbria, percentagens de $38,03 \%$ nos bovinos, $3,75 \%$ nos suinos e 0,13\% em ovinos. Na Sardenha. Sotcra, em 1900 encontrou, na província de Sassari, as seguintes percentagens de infestação: bovinos $90 \%$, ovinos $50 \%$ e suínos 6 a 7\%. Putzu, em colaboração com Doneddu, enconirou em Cagliari, as seguintes percentagens: hovinos $11,6 \%$, suínos $0.82 \%$ e ovinos e equinos $0 \%$. Notou. entretanto, que os bovinos provenientes das regiōes montanhosas não apresentavam essa parasitose, mas os que provinham de regiōes baixas e pantanosas, estavam altamente infestados.

Na América do Norte. Macath, citando Salmon, apresenta dados de 1298 e 1899, nos quais notam-se as seguintes percentagens de jncidéncia: suínos 1 para 24.000, ovinos 1 para 60.000, bovinos 1 para 1.500.000. Em Luisiana, de 5 a $20 \%$ dos suínos estavam infestados; no Missouri, sòmente 1\%; em Montreal (Canadá), 3\% dos suínos apresentavam essa parasitose. Nos Estados Unidos da América, em 1924, sôbre 50 milhões de suínos abatidos sob inspeção federal, foi observada incidência de 1 para 2.500; sôbre 12 milhões de ovinos, foram observados 212 animais atacados. Durante o ano de 1935, foram observados cistos em animais abatidos em Nashville T'ennessee, Filadélfia, Oklahoma City, St. Joseph e Richmond. Afirma o autor estar aumentando nesse país a incidência dessa parasitose em suínos.

BELDING cita percentagens de incidência do verme adulto, em cães, atingindo 25 a $28 \%$ na Islândia, 40 a $50 \%$ no sul da Austrália, $29 \%$ no Punjab (Ín. dia); afirma ser rara nos Estados Unidos da América e na Inglaterra, embora a hidatidose seja comum no gado e nos animais domésticos da Grã-Bretanha. SAwITz diz ser freqüente a verificação dessa parasitose em ovinos, bovinos e suínos dos Estados Unidos. Craig e Faust afirmam que a infestação de cães, na Islândia, não ultrapassa $28 \%$; a incidência da hidatiỏose humana nesse país, segundo êsses autores, caiu de aproximadamente 20 a $1 \%$; dizem também que na Pomerânia, onde são infestados de 37 a $64 \%$ dos bovinos, 27 a $51 \%$ dos ovinos e 4,9 a $12,8 \%$ dos suínos, a infestação humana não ultrapassa 0,07 a $0,08 \%$. Apresenta também incidência, na Síria e Palestina de $25 \%$ dos suínos, $70 \%$ dos ovinos, $40 \%$ dos bovinos e $100 \%$ dos camelos.

Prieto, citando Madelung e Sahlmann, apresenta dados de Mecklemburgo (Alemanha), com incidência em 5-8\% de hidatidose em suinos, 25-50\% em bovinos e $75 \%$ em ovinos. Afirma que, nesse país, tem havido um crescente aumento na incidência da hidatidose suína, e diminuição nas outras espécies.

Apresenta, a seguir, as percentagens de incidência observadas em vários ma. tadouros espanhois: 
M A ' ' A D O U R O S (Percentagens)

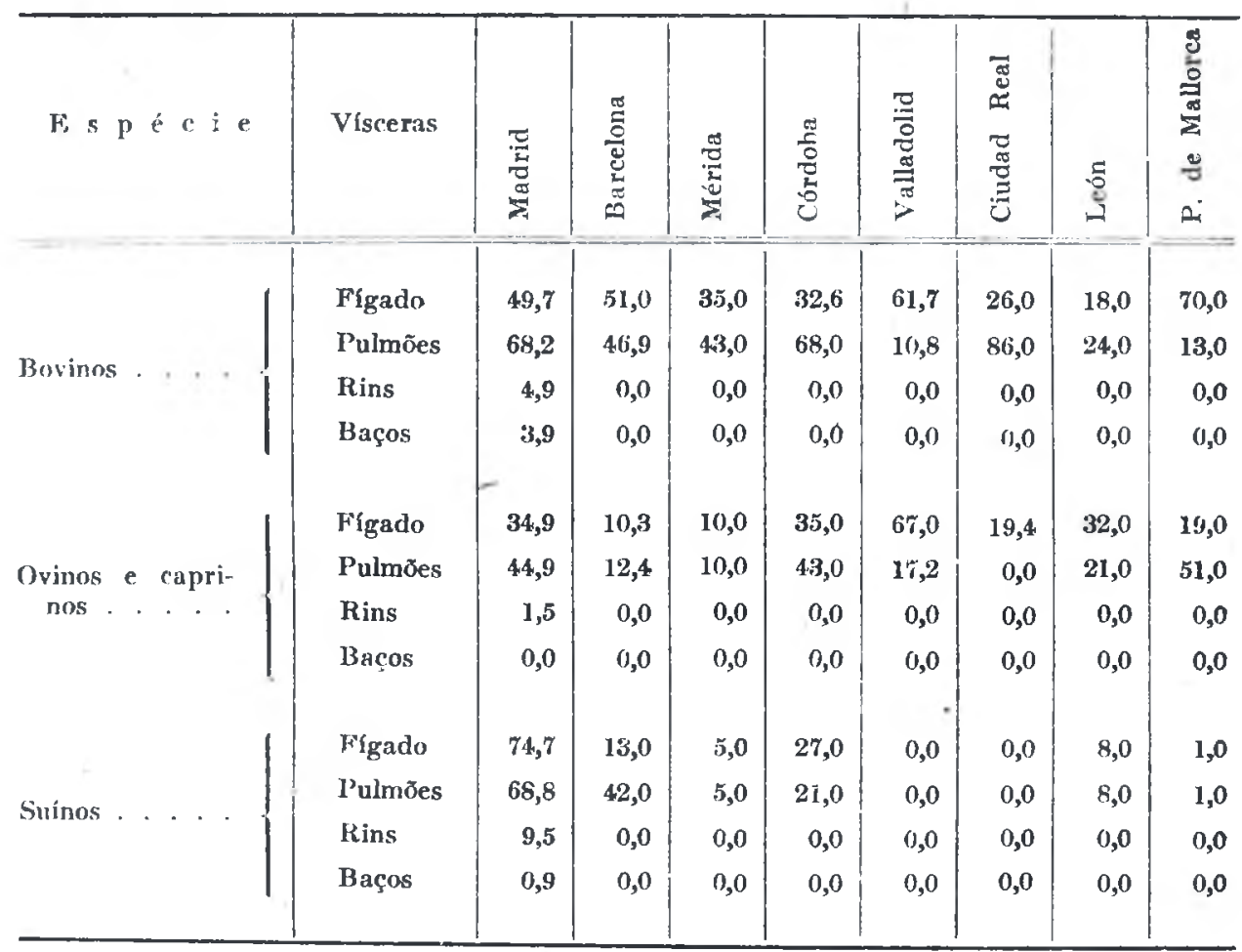

Fethers apresenta, de acôrdo com Ross, percentagem de 30\% de incidência nos ovinos da Austrália, dizendo ser êste país a "pátria clássica dessa enfermidade".

Howell, em 4 matadouros da Inglaterra (Gales), encontrou as seguintes percentagens de incidência:

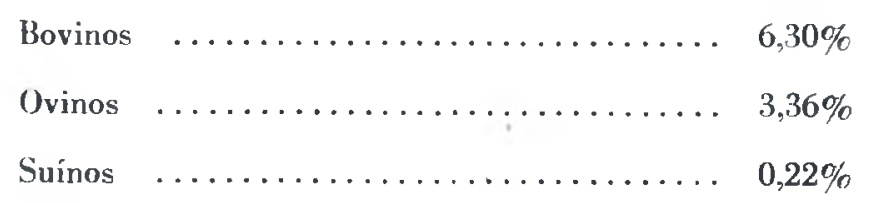

Barnett encontrou, na Nova Zelândia, $43 \%$ dos carneiros e $46 \%$ dos bovinos apresentando esta parasitose.

SAco, estudando a incidência dessa parasitose no Perú, observou, de 1938 a 1947, as seguintes percentagens de infestaçāo: 


\begin{tabular}{|c|c|c|c|c|}
\hline & & $\begin{array}{l}\text { No de animais abatidos } \\
\text { de } 1938 \text { a } 1947\end{array}$ & $\begin{array}{c}\text { Percentagens inédias } \\
\text { de incidência em } \\
\text { fígados }\end{array}$ & $\begin{array}{l}\text { Percentagens médias } \\
\text { de incidência em } \\
\text { pulmōes }\end{array}$ \\
\hline Ovinos & $\ldots \ldots \ldots$ & 861.029 & 11,27 & 11,84 \\
\hline Caprinos & $\ldots \ldots$ & 62.795 & 0,54 & 3,89 \\
\hline Suinos & $\ldots \ldots \ldots$ & 310.100 & 1,31 & 1,41 \\
\hline Rovinos & $\ldots \ldots \ldots$ & 940.303 & 1,19 & 0,96 \\
\hline
\end{tabular}

Vogelsang e Herrera, estudando essa parasitose na Venezuela, revelam jamais ter encontrado um único cisto hidático em milhares de bovinos abatidos no país; encontraram vários casos de hidatidose suína, mas não apresentam percentagens.

Baldomir verificou, no Uruguai, em 1936 , rejeiçāo de $32,94 \%$ de fígados de bovinos adultos; afirma que a maioria destas condenaçōes foi devida à hidatidose, concluindo que aproximadamente $80 \%$ dos bovinos adultos abatidos nesse país, são portadores dessa parasitose.

SERRES apresenta as seguintes percentagens de incidência na Argentina:

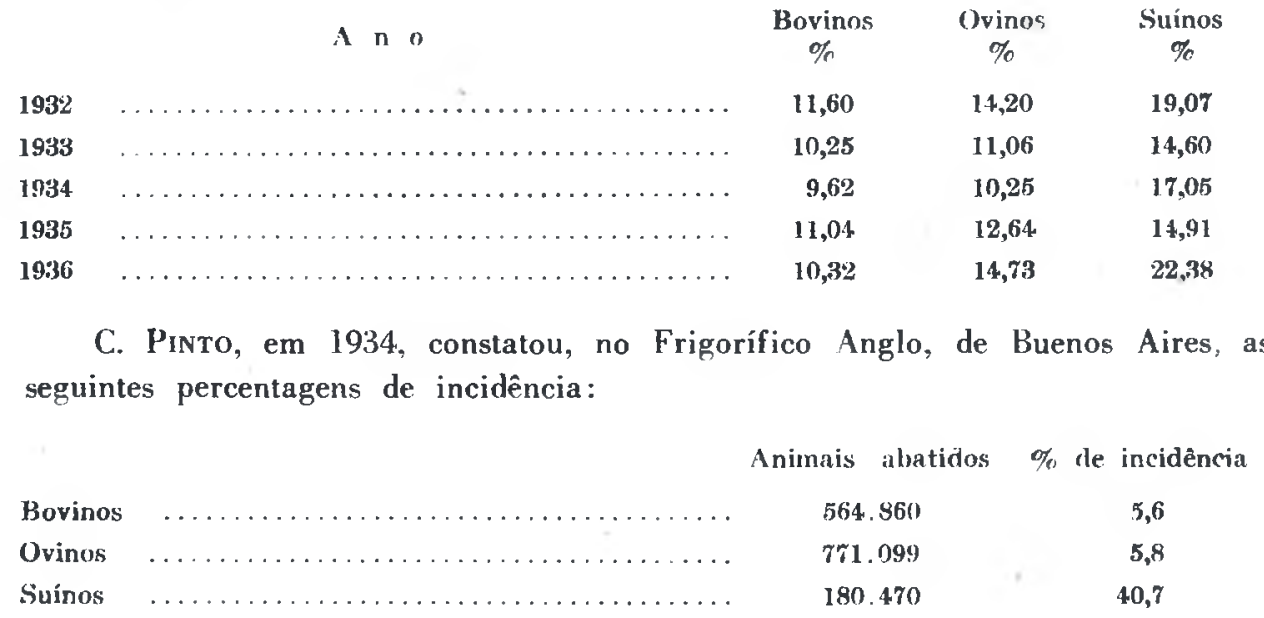

Carballo Pou afirma ter encontrado, de 1928 a 1929, no Frigorífico Artigas, de Montevidéu, percentagens de incidência de $60,5 \%$ em figados de novilhos "chilled" e "frozen", e de $68,07 \%$ em vacas. Cita Burghoffer que, estudando a hidatidose na Hungria, em 1933, observou, no matadouro de Budapest, as seguintes percentagens: 


$\begin{array}{cc}\text { Animais abatidos } & \% \text { de incidencia } \\ 1.769 & 17,3 \\ 10.325 & 1,8 \\ 1.710 & 7,1 \\ 1.460 & 2,1\end{array}$

Cita o mesmo autor, Bouin e JASAS que, em 1920, encontraram esta parasitose muito difundida no Marrocos, principalmente em camelos, menos em bo. vinos, ovinos e suinos. Esses autores. necropsiando 71 cães, observaram 14,08\% de parasitismo pela tênia adulta.

Pinto e Almeida, em série de artigos a respeito, apresentam interessanteg elementos. dos quais citamos os seguintes:

1) Percentagens de infestaçāo de cães pelo Echinococcus granulosus em diversos países:

Islândia $\%$

2. Dinanatrea (Copenhague) . . . . . . . .

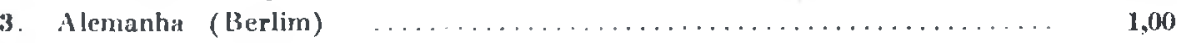

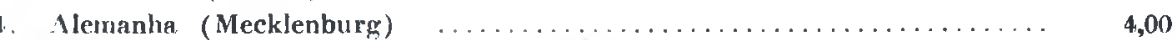

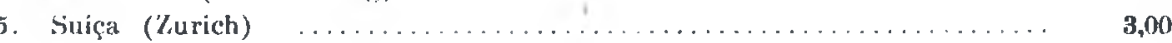

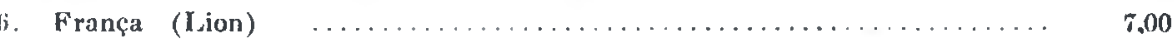

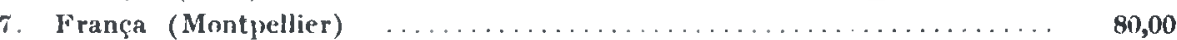

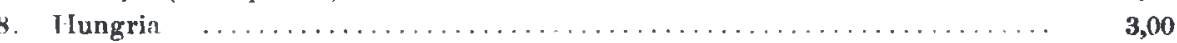

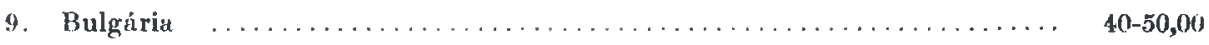

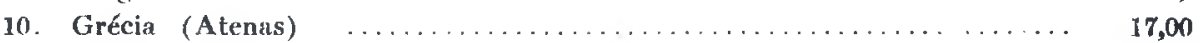

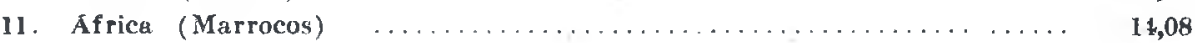

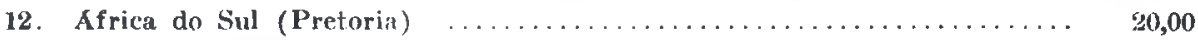

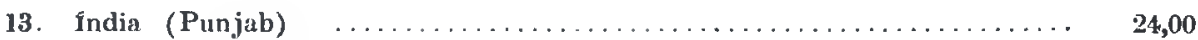

14. Jerusalem (Palestina) … . . . . . . . . . . . . . . .

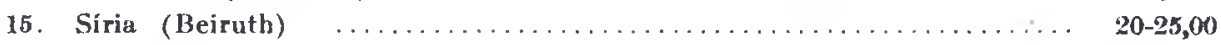

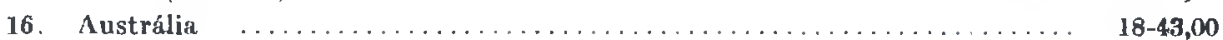

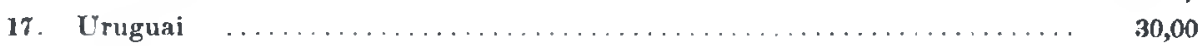

18. Brasil - Rio Grande do Sul — Santa Vitória $\ldots \ldots \ldots \ldots \ldots \ldots \ldots \ldots$ 3,5 a 40,0

19. I3rasil - Rio Grande do Sul - Porto Alegre ................... 0

20. Brasil - Rio de Janeiro ...............................

2) Citando Fairley e Penrose (1928), apresentam percentagens de incidência da forma larvar na Austrália; por êstes elementos, nota-se terem sido os animais de mais de 3 anos os mais parasitados, com os seguintes índices: bovinos $36,2 \%$, ovinos $26 \%$ e suínos $5.2 \%$.

3) Citando QuADVLIEG, observam o seguinte decréscimo na percentagem de incidência dessa zoonose numa província da Holanda. pela destruição de cadáveres ou órgãos parasitados: 
Rev. Fac. Med. Vet. S. Paulo _.. Vol. 4, fasc. 3, 1951

\begin{tabular}{|c|c|c|c|c|c|c|c|c|c|c|}
\hline$\Lambda \mathrm{n}$ i $\mathrm{m}$ a i $\mathrm{s}$ & 1926 & 1927 & 1928 & 1929 & 1930 & 1931 & 1932 & 1933 & 1934 & 1935 \\
\hline$\ldots \ldots \ldots \ldots$ & 15,0 & $\mathrm{J3}, 7$ & 10,9 & 9,5 & 8,9 & 8,8 & 6,6 & 6,1 & 5,5 & 4,2 \\
\hline Sumos $\quad \ldots \ldots \ldots \ldots \ldots$ & 1,0 & 1,0 & 0,9 & 0,6 & 0,4 & 0,3 & 0,6 & 0,5 & 0,5 & 0,4 \\
\hline Ovinos & 10,0 & 10,0 & 7,0 & 7,0 & 5,0 & 3,0 & 2,5 & 1,5 & 1,1 & 0,6 \\
\hline$\ldots \ldots \ldots \ldots$ & 8,4 & 8,2 & 8,1 & 6,7 , & 5,1 & 3,0 & 3,0 & 2,5 & 3,6 & 3 \\
\hline
\end{tabular}

4.) No Uruguai, a mortalidade humana por esta parasitose, aumentou de 0,717 a $1,160 \%$, nos anos de 1893 a 1932.

5) Na cidade de Buenos Aires, em 25 anos (1875 a 1900) foram registrados 970 casos de hidatidose humana, com as seguintes localizações:

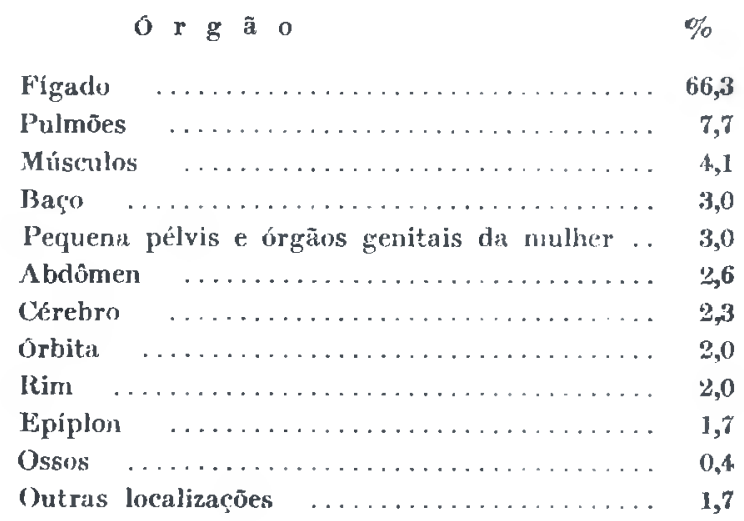

6) Na Argentina, segundo dados coligidos por Vegas, Cranwell e Spurr, verifica-se contínuo aumento no índice de incidência da hidatidose humana.

7) Apontam o Rio Grande do Sul como o maior fóco de hidatidose humana no Brasil. Com referência aos animais domésticos, citam os dados de Bss SEwitz (1908), que encontrou, em Santa Vitória, os seguintes indices de infestação: ovinos $95 \%$, suínos $75 \%$ e bovinos $29 \%$. Citando Bkusou (1922-1937), relatam incidência de $75 \%$ nos suinos abatidos em Pôrto Alegre.

8) Afirmam que, segundo pesquisas realizadas por Travassos, em 1914, 10\% dos suínos abatidos no matadouro do Distrito Federal, apresentavam-se infestados.

Os mesmos autores, em outro trabalho (1941), citam a incidência da hidatidose em bovinos e suínos abatidos em vários municipios do Estado do Rio Grande do Sul e no Matadouro Municipal do Distrito Federal: 
FREQUENCIA DA MIDATIDOSE NOS BOVINOS ABATIDOS NO FRIGORIFlCO ARMOUR DE IIVRAMENTO (RIO GRANDE DO SUI), DE 1918 A 1925. Segundo Prerco (1925).

\begin{tabular}{|c|c|c|c|c|c|c|}
\hline Datas & $\left\{\begin{array}{l}\text { No de bovi- } \\
\text { nos abntidos }\end{array}\right.$ & $\begin{array}{l}\text { \% no } \\
\text { tígado }\end{array}$ & $\begin{array}{l}\% \text { nos } \\
\text { pulmões }\end{array}$ & $\begin{array}{l}1 / 0 \text { no } \\
\text { coração }\end{array}$ & $\begin{array}{l}\% \text { nos } \\
\text { rins }\end{array}$ & $1 \%$ no baço \\
\hline 1918 & 17.922 & 2,666 & 2,21 . & 0,017 & $\ldots$ & $\ldots$ \\
\hline 1919 & 30.42 .6 & 3,99 & 2,78 & 0,011 & 0,003 & 0,003 \\
\hline 1920 & 37.04 .1 & 9,39 & 3,38 & 0,018 & - & 0,08 \\
\hline 1021 & 73.276 & 8,84 & 3,72 & 0,005 & - & 0,10 \\
\hline 1922 & $28 \cdot 116$ & 17,02 & 5,03 & 0,024 & - & 1,20 \\
\hline 1923 & 71.035 & 13,81 & - $\quad 1,17$ & 0,022 & - & 0,59 \\
\hline 1924 & 75.916 & $15,8 \%$ & 2,75 & 0.015 & - & 0,98 \\
\hline 1925 & 77.408 & 17,00 & 2,21 & $1), 078$ & 0,62 & 0,56 \\
\hline
\end{tabular}

FREQUENCIA DA HIDATIDOSE FM BOVINOS ABATIDOS NO FRIGORIFIGO SWIFT, DA CIDADE DE RIO GRANDF, (E. DO R. GRANDE DO SUL). Segundo Ouvitik (1932).

$$
\text { b) } \because 1 \text { it } \mathrm{s}
$$

19331

1931

1932

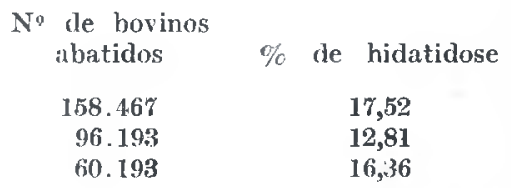

Os bovinos abatidos no Frigorifico Swift provieram de dezoito municípios do Estado do Rio Grande do Sul, situados na fronteira com o Uruguai.

FREQÜENCIA DA HIDATIDOSE WM 158.467 BOVINOS PROVENIENTISS DE 16 MUNICIPIOS DO ESTADO DO RIO GRANDE DO SUL, ABATTDOS NO FRIGORIFICO SWIFT. Segundo OLIVEira (1931).

\begin{tabular}{|c|c|}
\hline Municipios & $\%$ de hidatidose \\
\hline Jagua rão & 40,2 \\
\hline Santa Vitória & 33,8 \\
\hline Herval & 33,5 \\
\hline Arroio Grande & 29,8 \\
\hline Pinheiro Machado $\ldots \ldots \ldots \ldots \ldots$ & 23,2 \\
\hline Rio Grande $\ldots \ldots \ldots \ldots \ldots \ldots \ldots$ & 18,8 \\
\hline Piratini & 17,9 \\
\hline Bagé & 15,9 \\
\hline Caçapava. & 15,9 \\
\hline Dom Pedrito $\ldots \ldots \ldots \ldots \ldots \ldots \ldots$ & 15,5 \\
\hline Lavras $\quad \ldots \ldots \ldots \ldots \ldots \ldots \ldots \ldots$ & 12,2 \\
\hline São Gabriel $\ldots \ldots \ldots \ldots \ldots \ldots \ldots \ldots$ & 11,0 \\
\hline São Sepe $\ldots \ldots \ldots \ldots \ldots \ldots \ldots \ldots \ldots$ & 4,8 \\
\hline Rosário & 3,8 \\
\hline Júlio de Castilhos. & 2,0 \\
\hline$\ldots \ldots \ldots \ldots$ & 1,0 \\
\hline
\end{tabular}


HIDATIDOSE HEPATICA EM SUINOS ABATIDOS NO MATADOURO MUNICIPAL. DO DISTRITO FEJERAL, (RIO JE JANEIRO), DE 1927 A 1935 . Segundo O. M. de Calvatho é Sirva.

\begin{tabular}{|c|c|c|c|c|}
\hline & $D a t a s$ & $\begin{array}{l}\text { de suinos } \\
\text { abatidos }\end{array}$ & $\%$ de & hidatidose \\
\hline 1927 & $\ldots \ldots \ldots \ldots \ldots \ldots$ & 12.778 & & 8,16 \\
\hline 1928 & $\ldots \ldots \ldots \ldots \ldots \ldots \ldots \ldots \ldots \ldots \ldots$ & 12.227 & & 6,89 \\
\hline 1929 & $\ldots \ldots \ldots \ldots \ldots \ldots \ldots \ldots \ldots \ldots \ldots \ldots$ & 12.402 & & 4,57 \\
\hline 1930 & 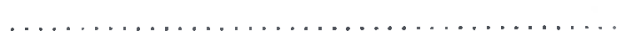 & 10.368 & & 3,40 \\
\hline 1931 & $\ldots \ldots \ldots \ldots \ldots \ldots \ldots \ldots \ldots \ldots \ldots \ldots$ & 9.970 & & 5,31 \\
\hline 1932 & $\cdots \cdots$ & 10.310 & & 3,16 \\
\hline 1933 & 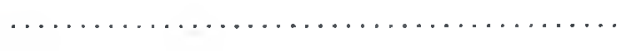 & 7.173 & & 4,99 \\
\hline 1934 & $\ldots \ldots \ldots \ldots \ldots \ldots \ldots \ldots \ldots \ldots$ & $7 . \$ 66$ & & 3,69 \\
\hline \multirow[t]{2}{*}{1935} & 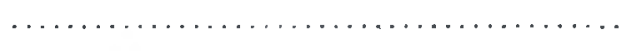 & 5.729 & & $\mathbf{4}, 67$ \\
\hline & & 89.123 & Média: & 4,98 \\
\hline
\end{tabular}

Relatam, ainda, os mesmos autores, as seguintes percentagens de incidencia da hidatidose em ovinos, bovinos e suínos, abatidos em vários municípios do Estado do Rio Grande do Sul, de 1905 a 1941:

\begin{tabular}{|c|c|c|c|}
\hline Mun i c i p i os & $\begin{array}{l}\text { Ovinos } \\
\%\end{array}$ & $\begin{array}{l}\text { Bovinos } \\
\%\end{array}$ & $\underset{\%}{\text { Suínos }}$ \\
\hline 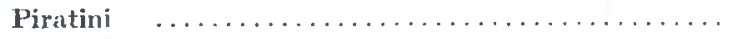 & & 55,2 & \\
\hline 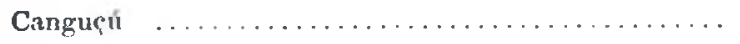 & & 53,2 & \\
\hline 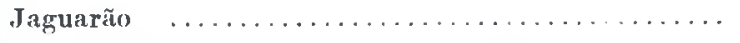 & 21,9 & 10,0 & \\
\hline 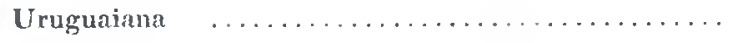 & & 40,0 & \\
\hline 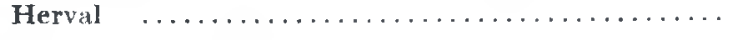 & & 37,0 & \\
\hline Santa Vitória do Palmar $\ldots \ldots \ldots \ldots \ldots \ldots \ldots$ & 95,0 & $\$ 3,8$ & 75,0 \\
\hline 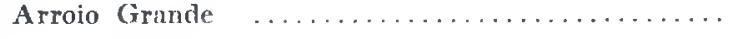 & & 29,8 & \\
\hline 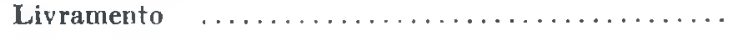 & & 27,0 & \\
\hline Rio Grande $\ldots \ldots \ldots \ldots$. & & 25,3 & \\
\hline 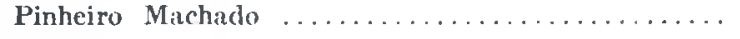 & & 23,3 & \\
\hline$\ldots \ldots \ldots \ldots \ldots \ldots$ & & 20,0 & \\
\hline 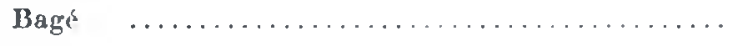 & & 19,4 & \\
\hline Don Pedrito & & 15,5 & \\
\hline 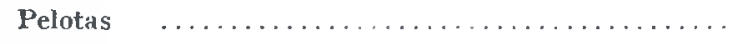 & 25,0 & 11,0 & - \\
\hline 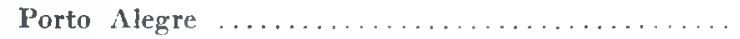 & - & $\cdots$ & 75,0 \\
\hline
\end{tabular}

Meneghetti (1946) encontrou, no sul do Estado do Rio Grande do Sul, em 1945, percentagens de 60 a $70 \%$ de infestação em bovinos e até mais de 
80\% em ovinos; o mesmo autor afirma que, até dezembro de 1944, subiram a 497 os casos de hidatidose humana operados no Rio Grande do Sul; naturalmente que a percentagem de incidência humana é muito mais alta, se levarmos em conta que muitos doentes sucumbem sem tratamento, muitos não são hospita. lizados e muitos casos não são sequer diagnosticados. Apresenta, a seguir, alguns dados que julgamos interessante transcrever:

INO DH 1942

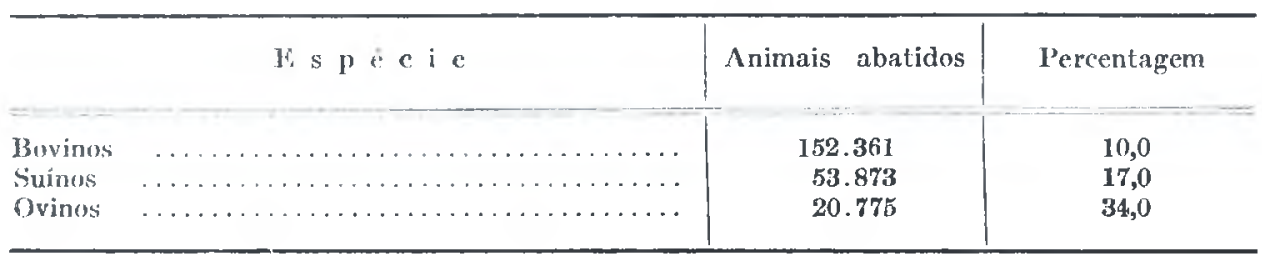

ANO DE 1943

\begin{tabular}{|c|c|c|c|}
\hline & lis pécie & Animais abatidos & Percentagem \\
\hline $\begin{array}{l}\text { BHovinos } \\
\text { Suínos } \\
\text { Ovinos }\end{array}$ & 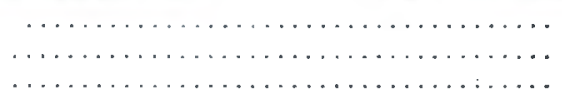 & $\begin{array}{r}176.536 \\
69.689 \\
81.769\end{array}$ & $\begin{array}{r}8,9 \\
20,0 \\
18,0\end{array}$ \\
\hline
\end{tabular}

INO DE 1944

\begin{tabular}{|c|c|c|c|}
\hline & Es p é c i e & Animais abatidos & Percentagem \\
\hline Bovinos & $\ldots \ldots \ldots \ldots \ldots \ldots \ldots \ldots \ldots \ldots$ & 143.139 & 11,0 \\
\hline Suínos & 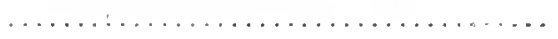 & $59.15 \%$ & 23,0 \\
\hline Ovinos & 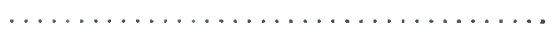 & 38.831 & 34,0 \\
\hline
\end{tabular}

Citando Mesquita Barbosa, apresenta os seguintes índices de infestação de ovinos, yor município, no Estado do Rio Grande do Sul, em 1945:

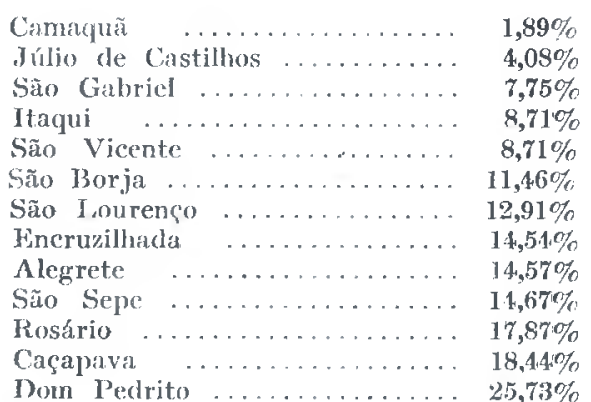

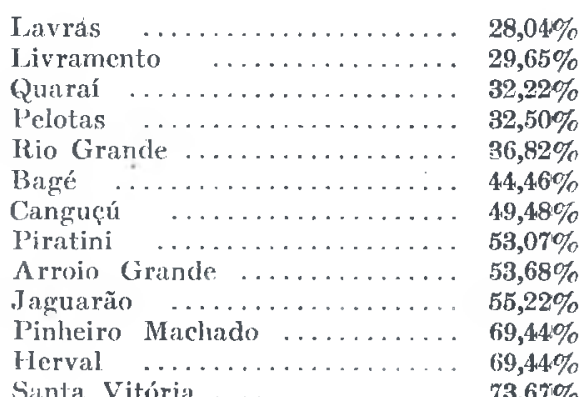


Meneghetti (1947) apresenta os seguintes dados de 1946, obtidos no Frigorífico Anglo, de Pelotas:

\begin{tabular}{|c|c|c|c|}
\hline & , & Abatidos & Percentagens \\
\hline Bovinos & 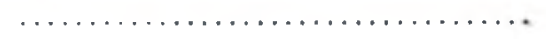 & 51.327 & 29,98 \\
\hline Suinos & 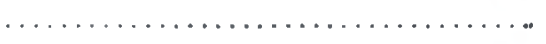 & 18.852 & 51,40 \\
\hline Ovinos & $\ldots \ldots \ldots \ldots \ldots \ldots \ldots \ldots \ldots \ldots \ldots \ldots$ & $32 .+172$ & $9,1,7$ \\
\hline
\end{tabular}

Apresenta ainda o autor dados fornecidos pela Diretoria dos Serviços de Higiene da Alimentação do Departamento Estadual de Saúde, pelos quais verifica-se que em 1946, 69,38\% dos ovinos abatidos em Pôrto Alegre apresertaram-se infestados. Quanto à equinococose bovina, cita o autor as scguintes percentagens de infestação: Gravataí com 56,51\%, Bagé com 35,28\%, Rio Grande com $34,93 \%$ e Uruguaiana com $34,22 \%$; observa que Gravataí, cidade onde é abatida a maior quantidade de bovinos para consumo da Capital, spresentá a mais alta percentagem de incidência; nota também que as outras cidades, em que a infestação é alta, estão situadas nas vizinhanças das fronteiras com o Uruguai e Argentina. Nas cidades de Vacaria e Antônio Prado, encontrou percentagem de $22 \%$ em suínos.

Cita ainda elementos de 1947, fornecidos pelo Serviço de Inspeção Federal do mesmo frigorífico, pelos quais evidencia-se elevação sensível, nas percentagens de incidência em muitos municípios, comparativamente aos dados publicados por Mesquita Barbosa:

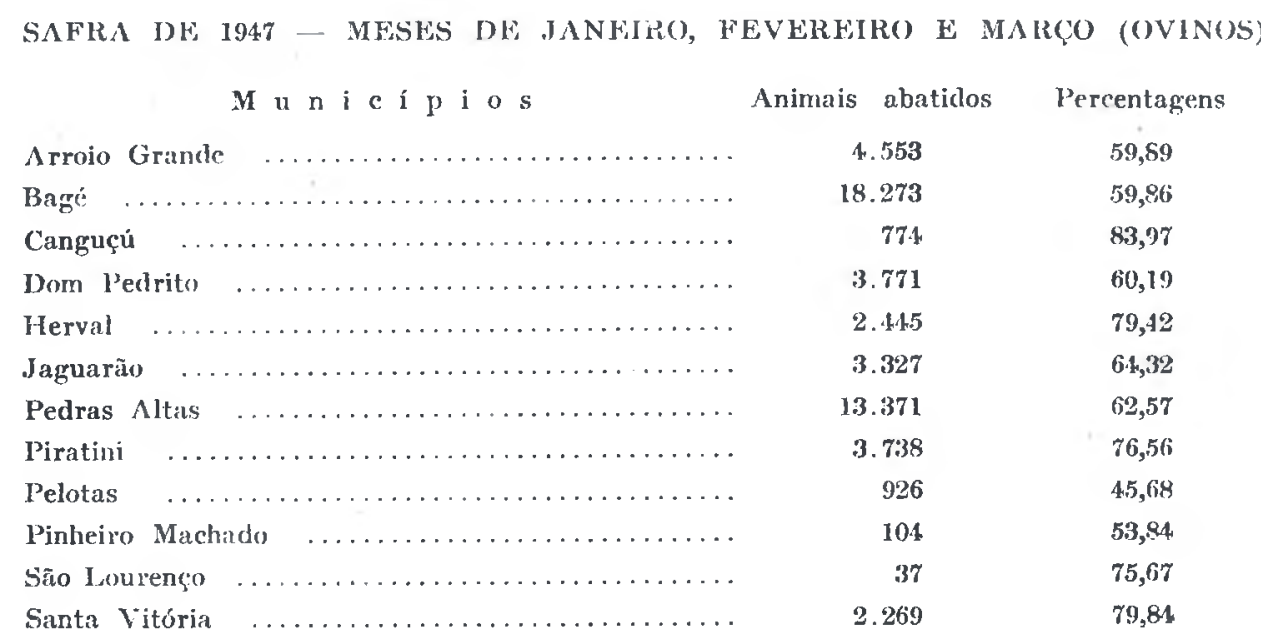


A ordem por localização dos cistos foi a seğuinle:

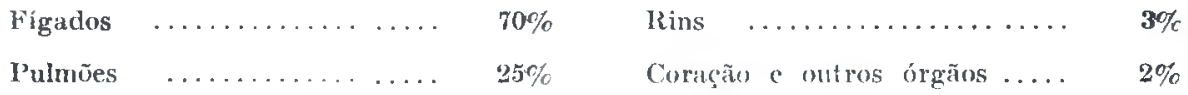

O mesmo autor obscrvou, em 1946, nas cidades de Arroio Crande, Jaguarão, Herval e Santa Vilória, infestações em $60 \%$ dos bovinos e $\mathrm{cm} 80 \%$ dos ovinos abatidos; verificou, também, no Frigorífico Anglo, de Pelotas, em ovinos procedentes de Jaguarão e Herval, cifras de $100 \%$ de infestação. Conclui dizendo ser a infestação ovina na zona sul do Estado do Rio Grande do Sul, duas vêzes maior que nas outras zonas do Estado; a infestação bovina, nessa zona é, segundo suas conclusões, quatro vêzes maior que nas outras zonas do Fstado.

Nós, em trabalho anterior (1949), analisando elementos obtidos no Ministério da Agricultura, salientamos que, sôbre 1.025 .000 bovinos abatidos no ano de 1946, em estabelecimentos situados no Brasil Central, observou-se 0,73\% de incidência, percentagem que subiu a 0,886 , sôbre 835.000 bovinos abatidos em 1947. Em outro trabalho, referente a suinos, e baseando-nos em dados fornecidos pelo mesmo Ministério, observamos, em 1946, sôbre 369.000 suínos abatidos na mesma região, incidência de $8,205 \%$, e em 194\%, sôbre 264.000 abates, incidência de 8,649\%. Nole-se que, nos dois anos citados, nos elementos por nós compulsados, não nos foi possível observar caso algum de equinococose extrahepática.

Almeida, em documentada tese sôbre o assunto, apresenta os seguintes dados, obtidos nas Inspetorias Regionais do Departamento de Inspeção de Produtos de Origem Animal do Ministério da Agricultura, referentes aos anos de 1934 a 1938 :

S U I N O S

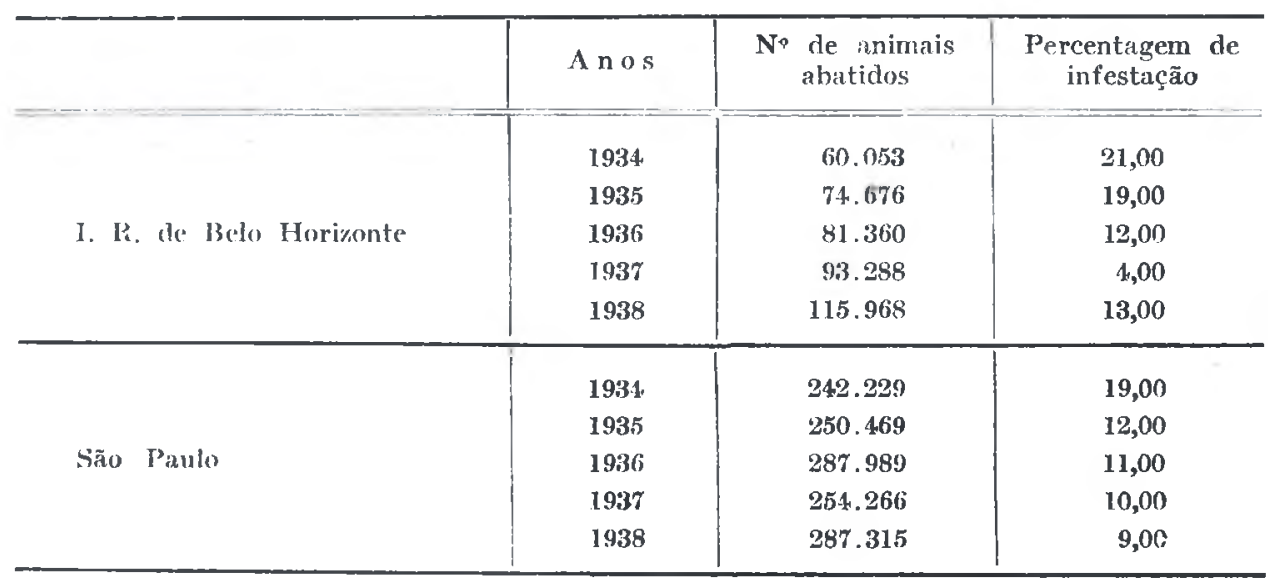




\begin{tabular}{|c|c|c|c|}
\hline Curitiba & $\begin{array}{l}1934 \\
1935 \\
1936 \\
1937 \\
1938\end{array}$ & $\begin{array}{l}182.845 \\
292.272 \\
298.543 \\
288.274 \\
343.122\end{array}$ & $\begin{array}{l}36,00 \\
35,00 \\
34,00 \\
30,00 \\
31,00\end{array}$ \\
\hline Niterói & $\begin{array}{l}1934 \\
1935 \\
1936 \\
1937 \\
1938\end{array}$ & $\begin{array}{l}-1.737 \\
15.857 \\
25.381 \\
22.555\end{array}$ & $\begin{array}{r}24,00 \\
9,00 \\
18,00 \\
10,00\end{array}$ \\
\hline Porto Alegre & $\begin{array}{l}1934 \\
1935 \\
1936 \\
1937 \\
1938\end{array}$ & $\begin{array}{l}208.884 \\
251.429 \\
290.254 \\
620.042 \\
620.833\end{array}$ & $\begin{array}{l}22,00 \\
35,00 \\
30,00 \\
30,00 \\
18,00\end{array}$ \\
\hline
\end{tabular}

O V I NOS

\begin{tabular}{c|c|c|c}
\hline & 1934 & 39.779 & 20,30 \\
Porto Alegre & 1935 & 45.639 & 21,35 \\
& 1936 & 41.207 & 31,19 \\
& 1937 & 54.701 & 11,83 \\
\hline
\end{tabular}

Com referência à equinococose visceral, apresenta o mesmo autor os seguintes elementos:

FREQUENCIA DE CISTOS PULMONARES W HEPATICOS NO BRASIL,

\begin{tabular}{l|c|c|c|c}
\hline Espécie & A nos & $\begin{array}{c}\text { No de animais } \\
\text { abatidos }\end{array}$ & $\begin{array}{c}\% \text { de localização } \\
\text { pulmonar }\end{array}$ & $\begin{array}{c}\% \text { de localização } \\
\text { hepáticru }\end{array}$ \\
\hline \hline Bovinos & 1925 & 408.494 & 3,25 & $8,8 \tau$ \\
Bovinos & 1938 & 764.675 & 7,34 & 10,8 \\
Suínos & 1938 & 620.833 & 1,80 & 18,0 \\
\hline
\end{tabular}

Sôbre a equinococose esplênica, apresenta elementos referentes a bovinos, ovinos e suínos no Brasil e, sem especificar espécie, sôbre 408.494 baços. encontrou 2.012 parasitados, isto é, $0,49 \%$. 
No referente à equinococose renal no Brasil, apresenta o seguinte quadro:

\begin{tabular}{|c|c|c|c|}
\hline & Es péci e & $\begin{array}{l}\mathrm{N}^{*} \text { de animais } \\
\text { abatidos }\end{array}$ & $\begin{array}{l}\% \text { de incidência } \\
\text { no rim }\end{array}$ \\
\hline$\stackrel{\text { Bovinos }}{ }$ & 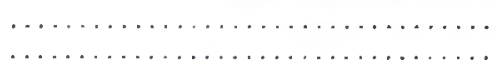 & $\begin{array}{l}408.494 \\
764.675\end{array}$ & $\begin{array}{l}0,117 \\
0,42\end{array}$ \\
\hline Suínos & 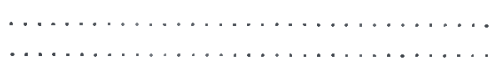 & $\begin{array}{l}52.225 \\
18.145\end{array}$ & $\begin{array}{l}0,12 \\
0,17\end{array}$ \\
\hline $\begin{array}{l}\text { Ovinos } \\
. \\
. \\
.\end{array}$ & 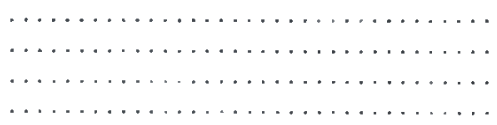 & $\begin{array}{l}39.759 \\
41.367 \\
54.701 \\
59.966\end{array}$ & $\begin{array}{l}0,2 \\
0,01 \\
0,04 \\
0,02\end{array}$ \\
\hline
\end{tabular}

Com relação à equinococose cardíaca, apresenta elementos do Estado do Rio Grande do Sul:

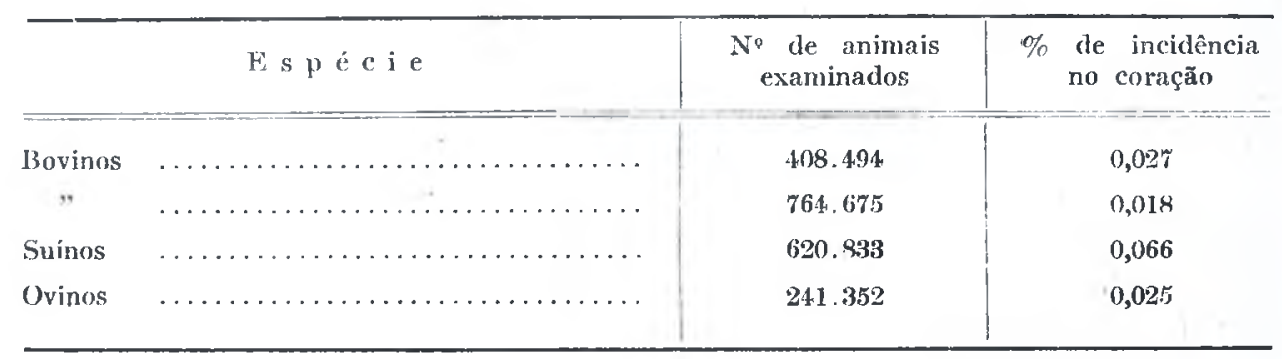

Afirma também que, no Rio Grande do Sul, os ovinos, suínos e bovinos têm papel preponderante na manutenção dos focos; nos Estados de São Paulo, Paraná, Santa Catarina, Rio de Janeiro, Mato Grosso e Goiás, são os suínos os principais responsáveis.

Sôbre a incidência da tênia adulta em intestinos de animais, afirma ter examinado 71 cáes e 32 gatos, sem encontrar caso algum de parasitismo.

Cita Hardegger (1905) que, examinando cães de Pôrto Alegre, não encontrou caso algum de parasitose pela tênia adulta.

Apresenta ainda percentagens de infestação de 18 a $43 \%$ em cães, na Austrália, e de $30 \%$ na Islândia e no Uruguai.

Pereira (1950), estudando a hidatidose no Rio Grande do Sul, observou, em fígados, incidência de $32,2 \%$ em ovinos, $17,7 \%$ em suínos e $8,4 \%$ em bovinos; em pulmões, a incidência verificada foi de $21 \% \mathrm{em}$ ovinos, $3,6 \% \mathrm{em}$ bovinos e $2,8 \%$ em suinos. 
De acôrdo com os autores citados, apresentamos as regiōes em que foram observadas maiores incidências da hidatidose suína no mundo:

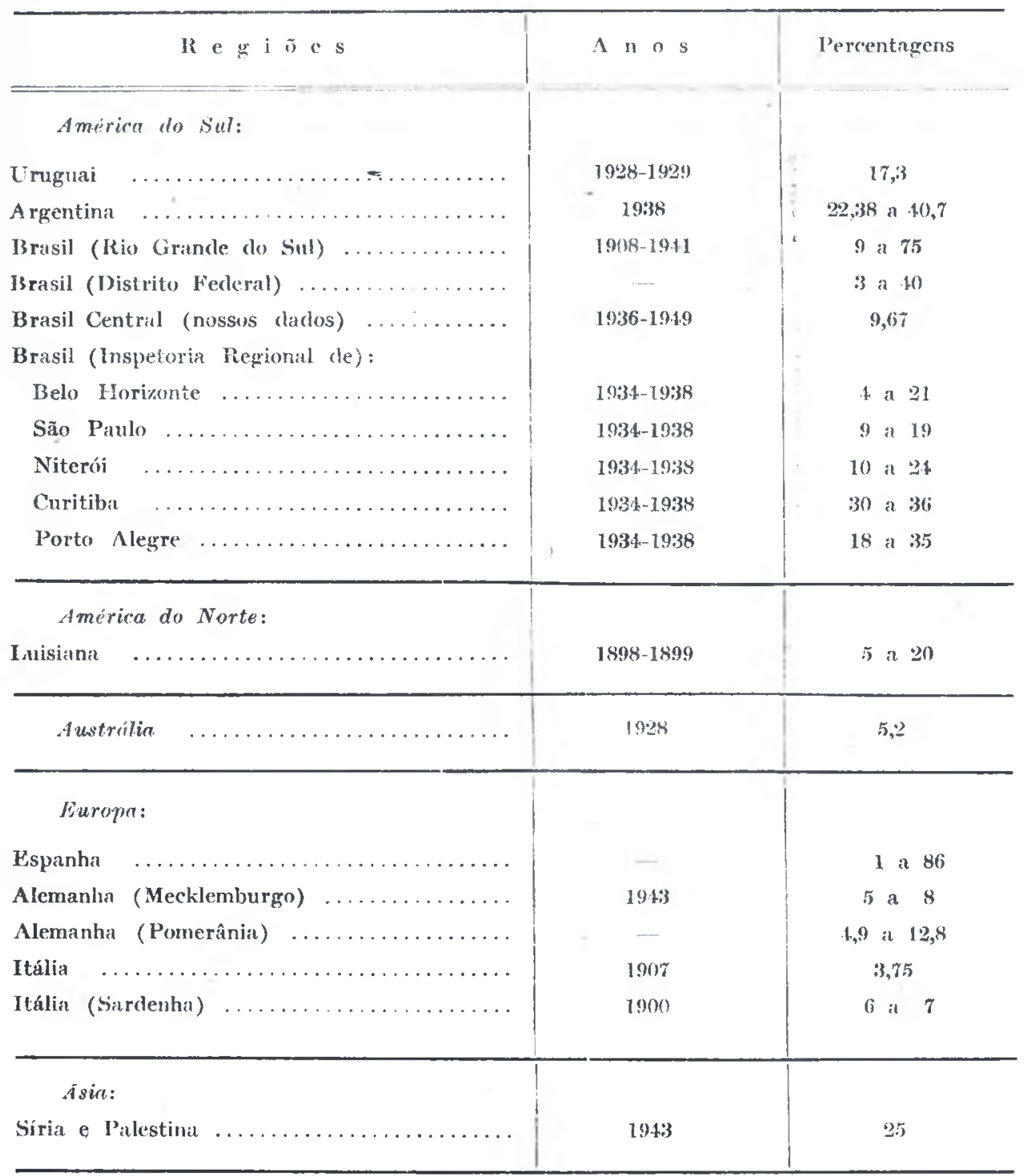

Com referência à incidência dessa parasitose na espécie humana, catalogamos elementos publicados por C. Pinto e Aimlida (1941), Meneghetti (1947) e Faillace (1951), relativos a casos verificados em municípios do Estado do Rio Grande do Sul. Pelo simples exame dos mesmos, verifica-se assustador aumento na incidência dessa doença. 


\begin{tabular}{|c|c|c|c|}
\hline M u & $\begin{array}{l}\text { C. Pinto e Almeida } \\
\text { (de } 1905 \text { a } 1941 \text { ) }\end{array}$ & $\begin{array}{l}\text { Meneghetti } \\
\text { (até 1946) }\end{array}$ & $\begin{array}{l}\text { Faillace } \\
\text { (até 1948) }\end{array}$ \\
\hline$\ldots \ldots \ldots \ldots \ldots \ldots \ldots \ldots \ldots$ & 89 & 135 & 196 \\
\hline 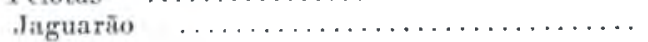 & 10 & 25 & 135 \\
\hline Rio Grande $\ldots \ldots \ldots \ldots \ldots \ldots \ldots \ldots \ldots$ & 4 & 20 & 87 \\
\hline 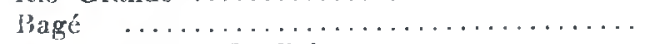 & 18 & 27 & 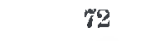 \\
\hline Santa Vitória do I’almar $\ldots \ldots \ldots \ldots \ldots \ldots$ & 26 & 30 & 48 \\
\hline 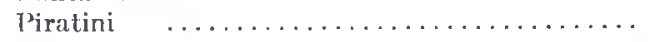 & 30 & 31 & 44 \\
\hline 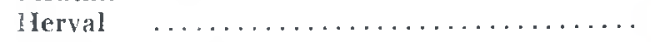 & 19 & 21 & $\mathbf{3 7}$ \\
\hline Dom Pedrito $\ldots \ldots \ldots \ldots \ldots \ldots \ldots \ldots \ldots$ & 8 & 24 & 29 \\
\hline 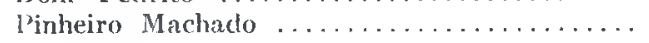 & 18 & 20 & 23 \\
\hline 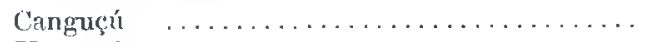 & 14 & 18 & 21 \\
\hline 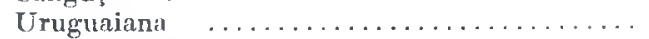 & fi & $16 i$ & 19 \\
\hline 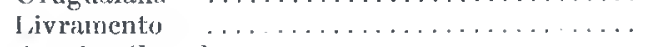 & 1 & 15 & 38 \\
\hline Arroio Grande $\ldots \ldots \ldots \ldots \ldots \ldots \ldots \ldots \ldots$ & 14 & 14 & 17 \\
\hline 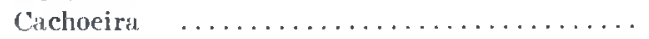 & 11 & 11 & 12 \\
\hline 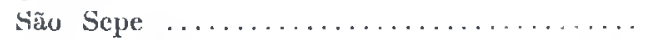 & :! & - & - \\
\hline Sũo Gabriel $\ldots \ldots \ldots \ldots \ldots \ldots \ldots \ldots \ldots$ & & - & 8 \\
\hline 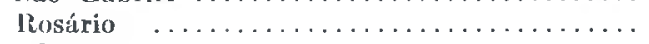 & -. & - & 7 \\
\hline 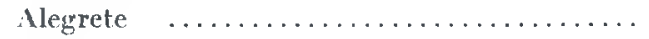 & is & -- & 6 \\
\hline 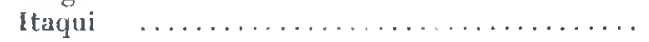 & & - & 6 \\
\hline 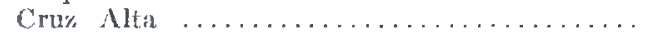 & 1 & - & 5 \\
\hline Porto Alegre $\ldots \ldots \ldots \ldots \ldots \ldots \ldots \ldots \ldots$ & 1 & $\ldots$ & 4 \\
\hline 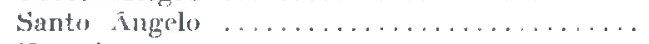 & & - & 3 \\
\hline 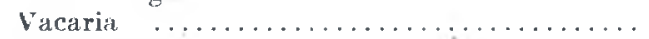 & $\mathfrak{l}$ & - & 2 \\
\hline Sào I courenço $\ldots \ldots \ldots \ldots \ldots \ldots \ldots \ldots \ldots \ldots$ & 1 & - & - \\
\hline 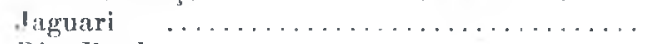 & & $-\cdot$ & 2 \\
\hline 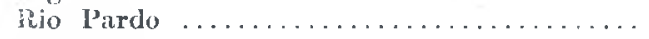 & - & - & 3 \\
\hline 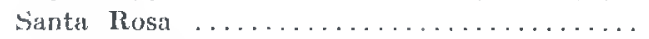 & & $-\ldots$ & 2 \\
\hline 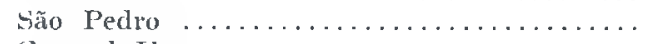 & & - & 2 \\
\hline General Vargas $\ldots \ldots \ldots \ldots \ldots \ldots \ldots \ldots$ & $\cdots$ & - & 2 \\
\hline 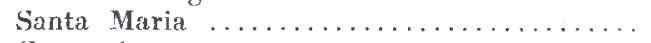 & - & - & 4 \\
\hline 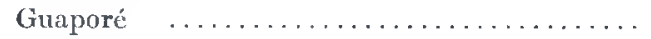 & 1 & - & $\mathbf{1}$ \\
\hline Fincruzilhada $\ldots \ldots \ldots \ldots \ldots \ldots \ldots$ & 1 & - & 1 \\
\hline Venâncio Aires $\ldots \ldots \ldots \ldots \ldots \ldots \ldots \ldots$ & 1 & - & 1 \\
\hline Sobradinho $\quad \ldots \ldots \ldots \ldots \ldots \ldots \ldots \ldots$ & - & - & 1 \\
\hline 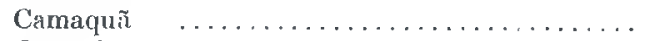 & 1 & - & 1 \\
\hline 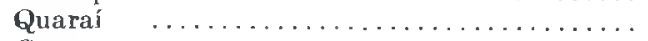 & 1 & - & 1 \\
\hline 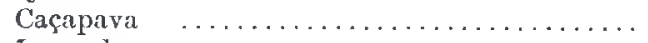 & 1 & $\cdots$ & - \\
\hline 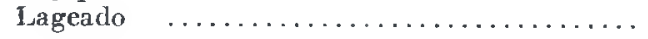 & 1 & - & - \\
\hline $\mathbf{T} \circ \mathrm{t} a$ & 28.5 & 413 & $8 \geq 0$ \\
\hline
\end{tabular}

$\mathrm{O}_{\mathrm{s}}$ elementos referentes à hidatidose, aqui coletados, afiguram-se-nos do mais alto interēsse, não só por revelarem altas percentagens de incidência em ovinos, bovinos e suínos, em muitos municípios brasileiros, mas, também, e principalmente. em razão da alta incidência, do constante e impressionante aumento de sua percentagem na espécie humana; neste particular, note-se ter sido catalogado, sòmente no Estado do Rio Grande do Sul, até 1941, um total de 285 casos

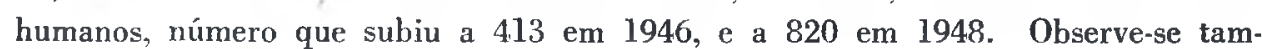
bém que a incidência da zoonose nos animais de açougue, corre paralela à da doença na espécie humana. em muitos dos municípios altamente infestados; esta 
última constatação revela bem o perigo a que estão expostas as populações dêsses municípios, dada a possível alta infestação de cães, pela forma adulta. Aliás, segundo C. Pinto e Almelda (1941), Bassewitz encontrou, em 1908, em Santa Vítória do Palmar, percentagens de infestação de cães, variando de 3,5 a 40\%. Acredilamos serem de grande interêsse e urgência, estudos sistemáticos sôbre a incidência da forma adulta do parasita, principalmente nos centros criatórios e de engorda, fornecedores de animais aos nossos estabelecimentos abatedores, assim como nas cidades em que se tenham evidenciado altas incidências da forma larvar, tanto em animais de abate como na espécie humana.

Pessôa, sôbre mais de 200 cães examinados na cidade de São Paulo, não encontrou caso algum de parasitose por Echinococcus granulosus.

\section{HS'PEFA NUROSH}

Carvalho, em tese sôbre o assunto, conclui o seguinte:

1) De janeiro a dezembro de 1927 , sôbre 12.778 porcos provenientes dos Estados de São Paulo, Minas Gerais, Rio de Janeiro e Espírito Santo, foram observadas incidências de $22,9 \%$ em rins e $10,2 \%$ em fígados.

2) No Sul do Brasil, no matadouro de Santa Cruz, sôbre suínos provenientes de São Paulo e de Minas Cerais, foram observadas incidênciaş de 90 a $100 \%$.

3) Sôbre 312 porcos provenientes do Ceará, foi verificado estarem todos infestados.

Cita o mesmo autor, BaUche e Bernard, que encontraram, em Annam, percentagens de $34,6 \%$ em rins e $4 \%$ em fígados.

Nós, segundo os elementos aqui apresentados e referentes a 4.463 .848 suínos abatidos no Brasil Central, de 1936 a 1949, observámos incidência de 21,264\% em fígados e $42,124 \%$ em rins.

\section{CTSTICHCUS TENUICOISS}

Beckwith \& Scott, estudando esta parasitose nos Estados Unidos da América do Norte durante um ano, examinando 500 animais semanalmente, afirmam ser esta doença, nesse país, mais freqüente em ovinos, seguindo-se os porcos e os bovinos; não apresentam, entretanto, percentagens.

Segundo nossos elementos, citados no quadro VIII dêste trabalho, a percentagem média de incidência, nos suinos abatidos no Brasil Central, foi de 2,469\%, de 1936 a 1949. 


\section{SUMĀRIO F CONCLUSŌES}

O trabalho refere-se à incidência percentual das várias causas de rejeição de carcaças e de vísceras de suínos abatidos em estabelecimentos industriais situados no Brasil Central, funcionando sob Inspeção Veterinária Federal, nos anos de 1936 a 1949 , e provenientes não só dessa região, mas também de ou. iras, que a ela fornecem suínos para abate. Durante êsses 14 anos, foi abatido nessa região, sob inspeção, um tolal de 4.463 .848 suínos, número sôbre o qual haseiam-se as percentagens apresentadas.

São inicialmente citadas tôdas as causas de rejeição de carcaças e de vísceras, assim como as respectivas percentagens de incidência; são, a seguir, feitos comentários sôbre as referidas çausas.

As carcaças que apresentaram uma ou mais das várias causas de rejeição, tiveram o seguinte destino:

\section{N. ${ }^{\circ}$ de carcaças}

Destinadas à fabricação de salsichas e conservas ..

Destinadas̀ à salga $\ldots \ldots \ldots \ldots \ldots \ldots \ldots \ldots$

Destinadas à fabricação de banha

Foram seis as principais causas de rejeição de carcaças e de vísceras de suínos abatidos no Brasil Central, no período estudado:

1) Cisticercose (Cysticercus cellulosae).

2) Equinococose ou hidatidose.

3) Estefanurose (Stephanurus dentatus, Diesıng 1839).

4) Cysticercus tenuicolis.

5) Tuberculose.

6) Más condições de transporte (animais contundidos e mortos em vagões e em currais).

A cisticercose suína incidiu sôbre, em média, $6.362 \%$ das carcaças, $5,627 \%$ das cabeças, $5,369 \%$ das línguas e $5,286 \%$ dos coraçóes.

A percentagem de incidência da cisticercose suína em carcaças, cabeças, línguas e coraçōes, não sofreu redução nos 14 anos estudados, o que significa ser necessária a intensificação das medidas profiláticas ora em uso, assim como a introdução de ontras, entre as quais destaca-se a vulgarização, entre os criadores, de métodos higiênicos de produção. 
A região estudada, assim como as que a ela fornecem suinos para abate. pódem ser consideradas como altamente infestadas pela cisticercose suína, quando comparadas às outras regiōes do mundo.

A cisticercose foi a doença que apresentou a mais alta percentagem de incidência em carcaças.

A cisticercose foi responsável pela maior percentagem de envio de carcaças à fabricação de banha, de conservas e à salga.

A cisticercose foi a única parasitose causa de condenação de carcaças.

E' urgente a necessidade de uma ampla campanha de erradicação dessa parasitose.

As rejeições de carcaças por contusões, mortes em vagões e nos currais, reflexos das péssimas condiçōes em que são transportados nossos animais de abate, contribuiram com crescente percentagem, ascendendo de 0,188\% em 1936 a $0,740 \%$ em 1949 .

Das carcaças condenadas, $50,016 \%$ o foram por tercm os animais chegado mortos ou terem sucumbido nos currais.

Numericamente, situaram-se os rins em primeiro plano na condenação de órgãos, seguidos pelos fígados, pulmões, cabeças, línguas, corações, intestinos e baços.

Foram condenados 3.406 .835 rins $(76,320 \%$ do total abatido $) ; 42,124 \%$ o foram por estefanurose (Stephanurus dentatus Diesing, 1839), 17,379\% por nefrites, $11,409 \%$ por uronefrose e $3,247 \%$ por apresentarem colorações anormais. principalmente jeterícias e adipoxantoses.

Foram rejeitados 1.972 .907 fígados $(44,197 \%$ do total abatido); $21,264 \%$ o foram por estefanurose, $9,668 \%$ por hidatidose, $2,617 \%$ por peri-hepatites e $2,271 \%$ por colorações anormais, principalmente icterícias e adipoxantoses.

Foram condenados 1.511 .119 pulmões $(33,582 \%$ do total abatido); $21,526 \%$ o foram por terem os animais aspirado sangue e alimentos no periodo agônico, e $9.705 \%$ por apresentarem enfisema.

Foram rejeitadas 369.867 cabeças $(8,286 \%$ do total abatido $) ; 5,627 \%$ o foram por cisticercose (Cysticercus cellulosae) e 2,226\% por tuberculose.

Foram condenadas 289.618 línguas $(6,448 \%$ do total abatido); $5,369 \%$ o foram por cisticercose e $1,019 \%$ por tuberculose.

Foram rejeitados 331.215 corações $(7,420 \%$ do total abatido $) ; 5,286 \%$ o foram por cisticercose.

Foram, condenados 36.593 intestinos $(0,820 \%$ do total abatido $) ; 0,524 \%$ foram por tuberculose. 
Foram condenados 18.117 baços $(0.106 \%$ do total abatido); $0,325 \%$ o foram por tuberculose.

A hidatidose suína atingiu, en 1936, percentagem de incidência de 11,49\%, em fígados; tal percentagem baixou em 1941 a $3,79 \%$, para subir novamente em 1942 a $12,97 \%$ e manter-se alta até 1945 (11,13\%), baixando então a $6,50 \%$ em 1949 .

Sòmente 149 pulmōes e 72 rins apresentaram esta parasitose. Não foram sbservadas outras localizaçōes do parasita.

Pelos elementos apresentados, podemos concluir que a regiáo chamada Brasil Central, assim como as que a ela fornecem suínos para abate, já cstá invadida pela hidatidose, podendo mesmo ser mencionada como região altamente infestada.

Esta moléstia, em razão de sua alta percentagem de incidência em suínos, ovinos e bovinos, e também devido ao grande perigo que oferece ao homem, representado por mais de oitocentos casos humanos já diagnosticados no Brasil, está a exigir urgentes e rígidas medidas profiláticas.

A percentagem de incidência da estefanurose renal (Stephanurus dentatus, Diesing, 1839), subiu de 45,203 em 1936 a 65,991 em 1942, para decrescer, em 1949, a $29,009 \%$.

A localização hepática dêste parasita subiu de 19,215\% em 1936 a $30.979 \%$ em 1942, decrescendo em 1949 a $16,427 \%$.

A percentagem de incidência do Cysticercus lenuicolis em fígados, permaneceu ao redor de $1 \%$ até 1940 ; em 1941 sua incidência subiu a $4,049 \%$, e em 1942 a 5,542\%; em 1949, entretanto, baixou a 2,362\%. Esta parasitose só foi observada em 7 rins. Não foram observadas outras localizações dêsse parasita.

Acreditamos que as variações notadas nas percentagens de incidência das moléstias parasitárias citadas foram devidas às diferentes medidas sanitárias tomadas durante a criação dos animais, nas diversas regióes donde os mesmos provieram.

A percentagem de incidência da tuberculose em suínos decresceu sensivel. mente durante o período estudado, tanto em carcaças como em cabeças, línguas, pulmões, fígados, intestinos e baços, como se póde notar pelo quadro seguinte:

\begin{tabular}{c|c|c|c|c|c|c|c}
\hline Anos & Carcaças & Cabeças & Linguas & P'ulmões & Fígados & Intest. & Baços \\
\hline \hline 1936 & 3,166 & 3,135 & 1,373 & 1,479 & 1,226 & 0,794 & 0,487 \\
1949 & 0,758 & 0,670 & 0,254 & 0,261 & 0,115 & 0,111 & 0,068 \\
\hline
\end{tabular}

Das carcaças condenadas, $33,962 \%$ o foram devido à tuberculose. 


\section{SUMMARY ANI CONCLUSIONS}

The work refers to the percentual incidence of causes of pork rejections in slaughterhouses situated in Central Brazil, working under the Federal Meat Inspection, in the years from 1936 to 1949 . During these 14 years $4,463,848$ pigs were abated; the percentages were taken according to this number. The animals came not only from Central Brazil, but also from other regions of Brazil. We mention, first, all the causes of rejections of carcasses and visceras and their percentages of incidence; following, we comment the results. Due to the causes of rejection, the carcasses had the following destiny:

\begin{tabular}{|c|c|c|}
\hline \multicolumn{3}{|c|}{ Number of carcasses } \\
\hline Condermned & 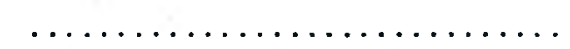 & 44,213 \\
\hline Destined for & sausage and canning industry. & 48,715 \\
\hline estined for & salting $\ldots$ & 52,192 \\
\hline Destined for & lard industry & 215,667 \\
\hline
\end{tabular}

We concluded that the principal causes of rejections of carcasses and visceras of swine in slaughterhouses of Central Brazil were the following ones:

1) Cysticercosis (Cysticercus cellulosae).

2) Echinococciasis or Hydatid disease.

3) Stephanuriasis (Stephanurus dentatus, Diesing, 1839).

4) Cysticercus tenuicollis.

5) Tuberculosis.

6) Very poor conditions of transportation for shipment (injured and dead in train cars and corrals).

The average of incidence of cysticercosis was $6.362 \%$ in carcasses, $5.627 \%$ in heads, $5.369 \%$ in tongues and $5.286 \%$ in hearts.

The percentage of incidence of cysticercosis in carcasses, heads, tongues and hearts did not decrease in the 14 studied years; this shaws that it is necessary to increase the vulgarization of hygienic processes of raising pigs. The studied region, as well as the others that provide pigs to it, may be considered highly infested by swine cysticercosis, when compared with other regions of the world.

Among the others, the cysticercosis was the disease which showed the greatest percentage of incidence in carcasses of swines.

The cysticercosis was responsible for the greatest percentage of the sending of carcasses. of swines to the industry of lard, sausages, canning and salting. 
The only parasitic disease which caused the condemning of carcasses of swines, was the cystieercosis.

Erradication of the cysticercosis is urgently needed.

The rejections of carcasses due to contusions, deaths in train cars and corrals, show the very poor conditions in which our animals are shipped; the percentage of rejection of carcasses due to this cause, increased from $0.188 \%$ in 1936 to $0.740 \%$ in 1949 .

Of the condemned carcasses, $50.016 \%$ were rejected due to this cause. Among the condemned organs, numerally, the kidneys are placed first, followed by livers, lungs, heads, tongues, hearts, intestines and spleens.

It has been condemned $3,406,835$ kidneys $(76.320 \%$ of the total slaughtered); $42.124 \%$ of them had this destiny due to stephanuriasis (Stephanuriss dentatus, Diesing, 1839), $17.379 \%$ due to nephritis, $11.409 \%$ due to echinococciasis, and $3.247 \%$ due to abnormal colorations, principally due to ichterus and xanthosis.

It has been condemned $1,972,907$ livers $(44.197 \%$ of the total abated); $21.264 \%$ due to stephanuriasis, $9.668 \%$ due to echinococciasis, $2.617 \%$ due to peri-hepatitis and $2.271 \%$ due to abnormal colorations, principally ichterus and xanthosis.

It has been condemned 1,511,119 lungs (33.582\% of the total slaughtered); $21.526 \%$ had this destiny due to aspiration of blood and food at the agonic moment, and $9.705 \%$ due to emphysema.

It has been rejected 369,867 heads $(8.286 \%$ of the total slaughtered $) ; 5,627 \%$ were rejected due to cysticercosis (C. cellulosae) and $2.226 \%$ due to tuberculosis.

It has been condemned 331,215 hearts $(7.420 \%$ of the total slaughtered); $5.286 \%$ were condemned due to cysticercosis.

It has heen condemned 289,618 tongues $(6.448 \%$ of the total slaughtered); $5.369 \%$ had this destiny due to cysticercosis, and $1.019 \%$ due to iuberculosis.

It has been condemned 36,593 intestines $(0.820 \%$ of the total abated); $0.524 \%$ were rejected due to tuberculosis.

It has heen rejected 18,117 spleens $(0.406 \%$ of the total slaughtered); $0.325 \%$ due to tuberculosis.

In livers, the hydatid disease reached, in 1936, the percentage of $11.49 \%$; this percentage decreased in 1941 to $8.79 \%$ and increased in 1942 to $12.97 \%$, remaining high until $1945(11.13 \%)$. In 1949 decreased to $6.50 \%$.

Only 149 lungs and 72 kidneys showed this parasite. No other localizations of the parasite were noted. 
We may conclude that Central Brazil is invaded by echinococciasis, and that this region may be called a highly infected one.

This disease, due to its high percentage of incidence in swines, sheep and bovines, and also due to the great danger to man, revealed by almost 900 human cases in Brazil, needs urgent and rigid prophylactic measures.

The percentage of incidence of renal stephanuriasis (Stephanurus dentalus, Diesing, 1839), increased from 45.203 in 1936 to 65.991 in 1942 , and decreased in 1949 to 29.009 .

The hepatic localization of this parasite increased from $19.215 \%$ in 1936 to $30.979 \%$ in 1942 , and decreased to $16.427 \%$ in 1949 .

The percentage of incidence of Cysticercus tenuicolis in livers, remained at about $1 \%$ until 1940; in 1941 its incidence increased to $4.049 \%$, and in 1942 to $5.542 \%$. In 1949 decreased to $2.362 \%$.

This disease was observed in only seven kidneys. No other localizations of the parasite were noted.

We believe that the changes in the percentages of incidence of the parasitic diseases cited, were due to the different sanitary measures taken in swine raising in the different regions from which they came.

The percentage of incidence of tuberculosis in swine decreased sensibly during the studied years, so much in carcasses, as in heads, tongues, lungs, livers, intestines and spleens, as we can see in the following table:

\begin{tabular}{c|c|c|c|c|c|c|c}
\hline Years & Carcasses & Heads & Tongues & Lungs & Livers & Intestines & Splecus \\
\hline 1936 & 3.166 & 3.135 & 1.373 & 1.479 & 1.226 & 0.794 & 0.457 \\
1949 & 0.778 & 0.670 & 0.254 & 0.261 & 0.195 & 0.111 & 0.068 \\
\hline
\end{tabular}

Of the condemned carcasses, $33.962 \%$ were rejected due to tuberculosis.

\section{HIBI.IOGRAFIA}

Armmida, J. M. L. - 1939 - Tese apresentada à Éscola Nac. de Vet. para concurso de Prof. Cat. de Doenças infecto-contagiosas e parasitárias dos animais domésticos, polícia sanitária e clínica. R. de Janeiro

Assis Ribeiro, P. - 1949 -- Incidência das várias causas de rejeição de súnos no Brasil Central. Prejuizo causado pelas mesmas nos anos de 1946-1947. Veterinária, R. de Janeiro, $3(1): 35-56$

Asgrs Ribeiro, P. - 1949 - Incidência das causas de rejeição de bovinos abatidos no Brasil Central. Prejuizo causado pelas mesmas nos anos de 1946-1947. Rez'. Fac. Med. Vet., S. Paulo, 4(1):167-183 
BalnomiR, A. - 1937 - Ia hidatidosis. Rev. Aso. Rural Uruguay, 14(7-8):58-63

B ARNETT - 1940 - Hydatid disease (Hditorial). Vet. Rec., 62(27):495-7

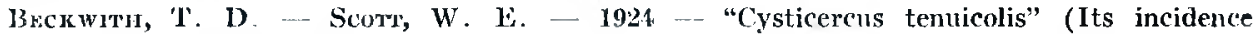
and immunological reactions.). Am. I. Hyy., $4(1)$

Bredina, D. I. - 1942 - 'Textbook of clinical Parasitology. New York, D. Appleton-Century Co.

Bestriereciea, L. - 1940 Contribución al estudio de la Cisticercosis porcina, en Venezuela. Rer. Pecuaria, Caracas, (23):11-6

Bnumpt, H. - 1949 - Précis de parasitologie. fème. éd. Paris, Masson \& ('ie.

Carbatro Pou, M. - 1938 - Consideraciones sobre el problema de la cquinococosis. Buenos $\Lambda$ ires, Imprenta de la Iniversidad

Cikvalio, A. D. - s.d. - Estephanuriase - . Iese apresentada à Cátedra le lnspeção e Conservação de Carnes, Leite e P'rod. de Origem Animal da Fsscola de Agricultura e Medicina Veterinária. IR. de Janeiro, 'lip. Jornal do Comércio

Crala, C. F. - Fatst, F. C. - 1943 - Clinical Parasitology. 3rd. ed. Philadelphia, Lea \& Febiger

DAvıs, J. H. - - 1947 - Hydatid disease or echinococciasis cansed by "lichinococcus granulosus": with special reference to Uruguay. Arch. Int. Hidatidosis, Montevidér), y(1-2):219-30

Enelmann, R. -..- 1943 - 'rext-book of neat Hygiene, sth, ed, rev, Mohler and kichhoin. Philadelphia, Lea \& Febiger

Fanlace, J. M. - 1951 - Hidatidose - Uma doença em progressão no Rio Giande do Sul. Rev. Med. R. Gr. Sul, $7(42): 3-8$

Fetriers, G. - 1942 - Lal hidatidosis. La urgencia de medidas para su eradicación. Gac. Camperr, Bs. Aires, 12(59):19-20

Hownst, N. - 1940 - Hydatid disease in Wales. Tet. Rec., 52(27):493-5

I.omato, A. V. - 1935 -... Cysticercose e tuberculose nos suinos do Paraná (Aspecto sanitúrio e econòmico). Rez. Dep. Nac, I'rod. An., R. de Janeiro, 2(4,5 6):407-10

Mada'T, ' 1 . B. 1941 - The epidemiology of hydatid ("Hchinococcus") disease in Canada and in the United States. Arch. Int. Mydatidusis, Montevidéo, 5(1-2):5\$-80.

Matos, R. O. - 1943 - Sôbre a incidencia do "Metastrongilus salnii" (Gedoclst 1923.) Nota prévia. Rev. Fruc. Med. Vel., S. Paulo, 2(3):211-12

Mrengiterru, M. - 1945 - Contribuição no estudo da hidatidose no Rio Grande do Sul. Arq. Dep. Est. Saúde R. G. Sul, Porto Alegre, 6:145-55

Mentererri, M. - 1946 -- A hidatidose no Rio Grande do Sul. Arch. Int. Hydatidosis, Montevidéo, 6(1-2):211-25

Meneghetr, M. - 1947 - Aspecto atual da profilaxia contra a hidatidose no Rio Grande do Sul. Arch. Int. Hydatidosis, Montevidéo, $7(1-2-): 103-10$

Precoo, O. - 1926 - Estatística de verificações e apreensōes a sua importância. Bol. Soc. Bras. Med. Vet., R. de Janeiro, 2(8,9,10):375-89

Penems, P. A. - 1950 - Hidatidose animal no Rio Grande do Sul. Port.' Alegre, of. graf. "o Globo" 
Prsson, S. B. - 1946 - Parasitologia médica. São Paulo, Fd. Renascença s. A.

Prnto, C. - 1936 - Viagem de estudos científicos à Argentina. s. Paulo, Diret. Publ. Agr. Sec.' Agric.

Pinto, C. - Almeida, J. L. - 1937 - Echinococose ou hydatidose humana e animal, especialmente no Brasil. O Cumpo, R. de Janeiro, 8(87):19-22; (88):49-54; (90) :50-4; (93):65-9

Pinto, C. - Armidia, J. L. - 1941 - Hidatidose humana no Brasil. Arch. Int. Iydatidosis, Montevidéo, 5(1-2):143-70

Prikso, A. R. - 1944 - Equinococosis en Patologia comparada. Zootecuia, Córdoba, $5(9-10): 100-106$

Putzu, $\mathfrak{F}$ - 1930 - L'Echinococosi in Italia. Arch. Int. Hidatidosis, Montevidéo, 2 (1) $: 13-35$

Saco, T. R. - 1948 - Datos estadisticos y consideraciones sobre la incidencia de la "Hidatidosis" en el ganado de carniceria en el Perú. Rev. rac. Med. Vet., Livia, 3(2, 3, 4):83-91

Sawitz, $W$. - 1938 - Echinococcus infection in l.ouisiana. J. Parasit., 24(5):437-39

Serris, J. R. - 1938 - Ia hidatidosis - Problema nacional sanitário y economico. Rev. Med. Vet., Buenos Aires, 20(9):389-96

Viljoex, N. F. - 1937 - Cysticercosis in swine and bovines, with special reference to South African conditions. Onderstepoort Jour., $9(2): 337-570$,

VII.Joen, N. F. - 1939 - Suggestions for the eradication of Cysticercosis-taeniasis. Jour. South African Yet. Med. Ass., 10(1):115-125

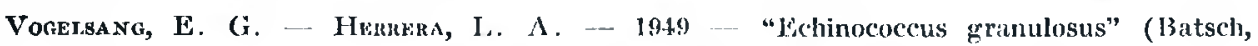
1786) en Venezuela. Rez'. Med. Vet. y I'aras., Caracas, 8(1-4):37-42 